\title{
FROM IBERIANS TO ROMANS: THE LATINIZATION OF IBERIAN ONOMASTICS THROUGH LATIN EPIGRAPHIC EVIDENCE
}

\author{
Noemí Moncunill \\ "A short time only is wanted before \\ they will be all Romans."
}

Strabo 3.2.15

I. INTRODUCTION

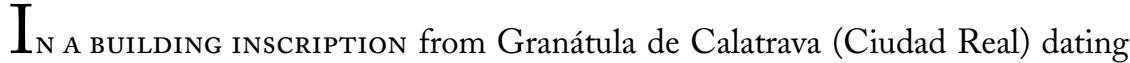
from Hadrian's time (CIL II 3221), three different individuals bearing the nomen Baebius are mentioned: the protagonist of the text, the Oretanus Publius Baebius Venustus, responsible for the construction of the bridge that is commemorated in the inscription; his father, Publius Baebius Venetius; and his grandfather, Publius Baebius Baesiscer (CIL II 3221):

$P($ ublius $) \cdot$ Baebius $\cdot$ Velnustus $\cdot P($ ubli $) \cdot$ Bae/bi $\cdot$ Veneti $\cdot f($ ilius $) \cdot P($ ubli $) \cdot B / a e b i \cdot$ Baesisce/ris - nepos. Or/etanus · peten/te · ordine $\cdot$ et $\cdot$ polpulo $\cdot$ in $\cdot$ hon/orem $\cdot$ domus / divinae $\cdot$ pontlem . fecit $\cdot$ ex $\cdot H S / X X C($ milia $) \cdot$ circensib/us $\cdot$ editis $\cdot$ dono $/ d($ edit $) \cdot i($ demque $) \cdot d($ edicavit $)$

Although all of them bear tria nomina, only the cognomen of the oldest, Baesiscer, is Iberian, whereas his descendants use Latin cognomina. This is one of many attested cases of the irreversible loss of Iberian onomastics across one or two generations, a phenomenon which has been directly linked to the Romanization of the indigenous elite and the gradual disappearance of vernacular languages in Hispania.

The aim of the present paper is to bring together all the Latin inscriptions displaying Iberian names in order to assess the sociolinguistic implications of onomastic shift amongst Iberians. It is important to note that most of these documents predate the promulgation of Vespasian's edict (ca A.D. 74), ${ }^{1}$ by which Latin citizenship was granted to all Hispanic provinces and following which the use of the nomen became widespread. ${ }^{2}$ The corpus analysed in this paper, which rarely postdates the first century A.D., is therefore interesting because it allows us to infer not only the legal condition of these Iberian people who wrote in Latin, but also linguistic attitudes, such as the continued use of indigenous names after the adoption of a nomen gentilicium, which can ultimately be taken

${ }^{1}$ Cf. Plin. 3.30: Vniversae Hispaniae Vespasianus Imperator Augustus iactatum procellis rei publicae Latium tribuit ("Vespasian offered to all of Hispania the Latin right which had been tossed about in the storms that assailed the state").

${ }^{2}$ Nonetheless, as Alföldy (1966: 51) observed, peregrine names are sporadically used in Hispania till the second century A.D.

PHoEnIX, VOL. 73 (2019) 1-2. 
as an indirect clue to identify language shift or maintenance in connection with the legal Romanization of the local inhabitants. ${ }^{3}$

In the following inscription from Empúries, dating from the first century A.D., for instance, the first member of the family to adopt tria nomina, Lucius Aemilius Montanus, no longer used a vernacular cognomen, and his Hispanic origin is only traceable thanks to the Iberian name of his father, Lacerilis (IRC III 50):

\section{L(ucio) Aemilio Montano Bacasitano Lacerilisf(ilio)}

In this particular case, we can see how access to Roman citizenship entailed the use of a fully Latin name, which probably went hand in hand with other significant cultural changes, such as the adoption of the Latin language as the primary language for public life and for interaction with the Roman administration. ${ }^{4}$

However, not all the available examples reveal such a rapid disappearance of the Iberian name once a Latin nomen had been acquired: on other occasions, the indigenous name presents greater resilience, lasting for several generations after the grant of citizenship. We can see this in another honorific inscription from Xàtiva (València), dating from the early first century A.D. The recipient of the inscription, Quintus Iunius Aenibel, whose cognomen is Iberian, is the son of an individual who already bore tria nomina, here mentioned, as usual, with his sole praenomen, Quintus (CIL II 3621):

$Q$ (uinto) Iunio $\cdot Q($ uinti) $\cdot f($ ilio $) /$ Gal(eria tribu) $\cdot$ Aenibeli

This shows how the local name could, in some instances, be retained over at least two generations of citizens. Cases of this kind might be interpreted as the expression of stronger ties with the traditional language of a place. It also demonstrates a certain degree of imbrication between the Roman and the local culture, as the individual, while fully integrated into the Roman juridical system, continues to display his cultural roots in public. It would obviously be an exaggeration to attribute this phenomenon to explicit cultural resistance, especially in the case of individuals who had sought or at least accepted Roman citizenship, which was probably rather a source of pride. In any case, it seems possible to observe here the manifestation of multiple cultural identities, Roman and local, which were not perceived as mutually exclusive.

\footnotetext{
${ }^{3}$ For the relationship between names and juridical status in the Roman world, see below, section II, $137-140$.

${ }^{4}$ On the relationship between the mastery of Latin and Roman citizenship, see Adams 2003: 562 and 2003a: 185-188. Primary evidence for the citizens' need to be fluent in Latin is Cic. Verr. 5.167: ciues ... Romanos qui et sermonis et iuris et multarum rerum societate iuncti sunt ("the citizens of Rome are united into a single community by language, law, and many other things"), and Suet. Claud. 16.2: splendidum uirum Graeciaeque prouinciae principem, uerum Latini sermonis ignarum, non modo albo iudicum erasit, sed in peregrinitatem redegit ("He [Claudius] not only struck from the list of jurors a man of high birth, a leading citizen of the province of Greece, because he did not know Latin, but even deprived him of the rights of citizenship").
} 
Another case, different from the ones mentioned above, but still significant in terms of linguistic behaviour, would be that of individuals who bore peregrine onomastics, but began to use Latin names. This appears to occur in the following inscription from Pinos Puente (Granada), dating from the first century в.c. Here again three different generations appear-the grandfather, Tascasecer; the father, Vrcestar; and the son, Nigellus - but, despite all of them being peregrini, the youngest of the family no longer bears, unlike his ancestors, an Iberian name (CIL II 2067):

Vrcestar Tascasec/eris f(ilius) Ilurconensis / an(norum) LXXXVII sit t(ibi) t(erra) l(evis) I Nigellus f(ilius) impensa s(ua) c(uravit).

It follows from this example that the abandonment of traditional onomastics cannot be linked exclusively to the acquisition of a nomen gentilicium: in cases like this one, the shift to Latin onomastics seems to arise from a personal choice rather than from a change in juridical condition. Examples of this kind are probably a direct consequence - the other side of the coin, so to speak-of the cases mentioned in the previous sections: the association between a full Latin nomenclature and a certain privileged status in Roman society must have entailed the perception that Latin was the language of the ruling power. It is likely, in these circumstances, that Latin names were seen as a sign of social prestige and distinction, regardless of the legal status of the person.

These cases not only show different rates in the switch from Iberian onomastics to Latin in relationship with the acquisition of a Latin nomen-and probably of Roman citizenship as well-but also demonstrate different linguistic attitude. It is possible that the cases of maintenance of local names denote a certain attachment to local identity, whereas the rapid adoption of a Latin name after acquiring citizenship or, even independently of this fact, shows a stronger willingness to present oneself as fully Roman. Beyond the individual cases, what interests us most here is to try to define general patterns in order to assess the role of Iberians in the spread of Latin in Hispania, and to identify to what extent the legal integration of the indigenous elites acted as an incentive for Latinization. In this respect, a comparative advantage when dealing with Iberian onomastics is that we have a high degree of certainty that these names really belong to local inhabitants, and not to other communities-either fully Latinized or not-coming from abroad, as might have occurred, for instance, with Celtic names in Britain. ${ }^{5}$ Iberian is an isolated non-Indo-European language, which makes Iberian names relatively easy to identify. Iberian onomastics are known through both Latin inscriptions and a large number of inscriptions in the Iberian language and script, the oldest dating back to the fifth century B.c., and this gives us a precise idea of the local naming patterns and their diachronic evolution. All this means that the survival of Iberian names in Latin inscrip-

${ }^{5}$ See Mullen 2007: 38-39. 
tions can be considered as positive proof of the use of Latin among indigenous populations.

Onomastic switching has been used in the past to assess the advance of Romanization in Hispania, ${ }^{6}$ but, in fact, there is still a notorious dearth of case studies focusing on the different ethnic and linguistic groups which coexisted in the Iberian Peninsula during the Iron Age. This complementary approach is, however, necessary to bring to light the different ways in which the indigenous population reacted to the presence of Rome. The fact that these local communities were not only different from a cultural point of view but also had very different levels of development in terms of urbanism, social and administrative structures, trade networks, and even literacy in the pre-Roman period, explains to a great extent their different rates and degrees of integration into the Roman world, and also the different strategies adopted by the Romans in order to impose control over their territory. ${ }^{7}$

\section{SOME METHODOLOGICAL CONSIDERATIONS}

The theoretical framework of this analysis rests on two complex questions: to what extent names are related to social status; and to what extent names can be taken as an identity marker. Regarding the first question, it should be borne in mind that in the Roman world personal names were not only relevant to identify one individual from another, but also revealed the bearer's legal and social status. This link between names and legal condition is, however, not absolutely straightforward, and the extent to which it is to be understood either as essentially rigid or merely as a broad trend has been a matter of debate. ${ }^{8}$ In a simplified way, individuals bearing duo or tria nomina are usually considered to be Roman citizens, whereas individuals with a single name, occasionally followed by the name of the father, are considered to be peregrines. The Latinized Iberian names would appear, in the case of citizens, as cognomina, and, in the second case, as the unique names of individuals. ${ }^{9}$

This issue is, nevertheless, slightly more complex. First, we must recognize that possible cases of usurpation or imitatio are formally undetectable and that these practices might have occurred, especially in remote locations. However, in general terms, and given that the acquisition of a nomen was regulated by

\footnotetext{
${ }^{6}$ See, for instance, Curchin 2004: 200; see also Cranford 2012, which nonetheless has the methodological limitation of not distinguishing between local cultures and their distinct naming patterns.

${ }^{7}$ On the conquest of Hispania and the integration of the local population, see Richardson 1986; Le Roux 1995; Barrandon 2011; Edmonson 2014.

${ }^{8}$ On the relationship between personal names and juridical status in the Roman world, see Alföldy 1966; Chastagnol 1995: 51-71, esp. 54; Dondin-Payre and Raepsaet-Charlier 2001: ii-iv; Raepsaet-Charlier 2009; Dondin-Payre 2011: 14-17.

${ }^{9}$ For the integration of indigenous names into the Roman onomastic formula, see Mayer 2002; Estarán 2009; Dondin-Payre 2012.
} 
the Roman authorities and its illegal usurpation was explicitly prosecuted, ${ }^{10}$ it is very likely that misuse was minimal. ${ }^{11}$ Secondly, the use of a simple name in certain contexts cannot be taken as conclusive proof of peregrine status, since the familiar name might differ from the official one. ${ }^{12}$ In any case, and taking into account these caveats, the general trend is that the acquisition of a nomen entails a change of status, with the acquisition of citizenship and ascent in provincial society.

The second question concerns code-switching in personal names: to what extent can it be considered as a clear identity marker ${ }^{13}$ Is there really a strong implicit relationship between one's choice of name and the manifestation of a cultural and linguistic background? In the particular case studied here, can we assume that the bearer of an Iberian name maintained stronger ties with his traditional language and culture than someone who had renounced his vernacular nomenclature? These questions confront us with the complex links between language and identity. ${ }^{14}$

Although it is not possible to get to the bottom of every individual case, nonetheless we can, as noted above, outline some general patterns of behaviour that might be significant. In the first place, the demise of Iberian onomastics occurs not long after the extinction of Iberian in the written domain: the last Iberian inscriptions date back to the time of Augustus, and in the early second century A.D. Iberian onomastics almost completely disappear from the epigraphic record. It is also noteworthy that the survival of Iberian names in Latin is comparatively rare: the total number of occurrences is in fact very limited if we compare it with other indigenous cultures of the Roman empire or, specifically, with the other peoples of the Iberian Peninsula. This needs to be put alongside the fact that, during the first centuries of Roman domination, Iberians continued to express themselves mainly in their own language, even in the public sphere, as evidenced by the richness of the Iberian epigraphic record during the republican period.

Taken together, all these elements suggest that the onomastic shift amongst Iberians - as recorded in the inscriptions compiled in this work-corresponds to a transition phase of profound and rapid cultural change. The culmination of this change entailed, first, the abandonment of the native language at the written level and, later-probably within just a few generations-linguistic substitution. One cannot rule out the possibility that in some residual cases-maybe in certain

\footnotetext{
${ }^{10}$ Raepsaet-Charlier 2009: 359 and 361-362. Cf. Suet. Claud. 25.3 and Cic. De off. 3.11.47, on the lex Papia de peregrinis, and CIL V, 5050, on the lex Anaunorum.

${ }^{11}$ Alföldy 1966: 38; Dondin-Payre and Raepsaet-Charlier 2001: ii; Raepsaet-Charlier 2009: 259-360.

${ }^{12}$ Mayer 2002: 193; see also below, 139.

${ }^{13}$ Adams 2003: 369-375 and 753; Estarán 2009.

${ }^{14}$ See Adams 2003: 751-753 and, for the specific case of Hispania, Beltrán 2011.
} 
remote rural areas-Iberian was spoken for longer, but this phenomenon lies entirely beyond the scope of the available documentation. ${ }^{15}$

As scholars attempt to discern the interaction between names and identity, they are seriously constrained by the characteristics of the available documentation: ${ }^{16}$ the sources are too often partial and misleading, as they only reflect what some individuals wanted to show in the public and official sphere. ${ }^{17}$ In the context of a society involved in a radical process of transformation, it is to be expected that individuals expressed their mixed identities in a wide variety of ways in order to adapt themselves to different contexts and communicative situations. We should therefore not exclude the possibility that the same person could use different names for official and private purposes, or for different audiences. ${ }^{18}$ This is what might have occurred in a bilingual inscription on a funerary urn from Arezzo, in Italy, which contains a bilingual commemoration, in Latin and Etruscan, of a single individual. ${ }^{19}$ Since the two names differ significantly, it would be tempting to interpret them as referring to different people, but the urn only contained the remains of one person, which has been taken as evidence that this individual had two different names, one in Etruscan, and another one in Latin (TLE 930):

Cn(aeus) $\cdot$ Laberius $\cdot A(u l i) \cdot f($ ilius $) \cdot /$ Pom (ptina) / a (ule) $\cdot$ haprni $\cdot$ a (uleśs / axratinalisa

While this kind of double nomenclature could have existed in the Iberian Peninsula as well, the fact is that such a phenomenon is very difficult to detect, especially given the scarcity of bilingual material. ${ }^{20}$ However, parallels provided by other cultural artefacts, such as this inscription, show that the individuals documented in our texts did not necessarily in their everyday life bear the names recorded in the Latin epigraphic sources, especially when we consider that most instances are found in lapidary epigraphy, which implies a strong component

${ }^{15}$ In this sense, it is also worth recalling the statement of Strabo (3.1.15), according to which the Turdetani, who occupied the valley of the Guadalquivir River, had already lost their language at the beginning of the principate.

${ }^{16}$ See for instance Dondin-Payre 2012; Mullen 2007: 36-38; Mullen 2013: 122-124.

${ }^{17}$ A similar problem can be observed in the Ascoli Bronze, as stressed by Beltrán (2011: 34 and n. 83), where individuals with a nomen do not bear a cognomen. As a matter of fact, the use of the cognomen was not to be generalized before the first century в.C., which constitutes an additional difficulty for detecting the indigenous element in Latin republican inscriptions.

${ }^{18} \mathrm{Cf}$., for instance, the case of the artisans from La Graufesenque, as interpreted by Adams (2003: 703-707). For other general considerations on a similar use of double names, see Adams 2003: 169-179, 213-221; Dondin Payre 2012: 25-26; Estarán 2016: 76.

${ }^{19}$ Adams 2003: 169-170; Estarán 2016: 124-125.

${ }^{20}$ Explicit evidence showing that the locals in Hispania could have had a double name is, in fact, very scarce, and perhaps only limited to a few bilingual inscriptions whose interpretation is far from clear. For an interpretation of them as containing two equivalent naming formulae, in Iberian and Latin, see Estarán 2016: 339-344 and 352-354. 
of public self-representation. Nevertheless, onomastic shift remains a valuable source of information for understanding cultural and linguistic change in antiquity. In some cases, as is the situation here, it even represents the last testimony to the existence of a language that would fall into oblivion soon after.

\section{IBERIAN PERSONAL NAMES}

Iberian is a pre-Roman, Palaeohispanic language directly documented by epigraphy alongside other languages spoken more or less in the same period in the Iberian Peninsula, such as Tartessian, ${ }^{21}$ Turdetanian, ${ }^{22}$ Celtiberian, Lusitanian, and perhaps Vasconic-Aquitanian. ${ }^{23}$ Within this multilingual patchwork, Iberian can roughly be placed in the regions bordering on the Mediterranean Sea, from Languedoc in the north to Eastern Andalusia in the south (fig. 1), reaching into the hinterland mainly along the rivers, particularly along the Ebro valley. In the Roman period the Iberian linguistic area was initially integrated into the provinces of Hispania Citerior and Ulterior, and from the time of $\mathrm{Au}-$ gustus into Hispania Tarraconensis and Baetica; further north, it also covered a small part of Gallia Narbonensis. As mentioned above, Iberian is not an Indo-European language: according to various forms of linguistic evidence, the Mediterranean-facing regions of the Peninsula, the Ebro Valley, and the area of the Pyrenees seem to have been occupied by non-Indo-European peoples, whereas the centre of the Peninsula and the Cantabrian and Atlantic basins were mostly inhabited by Celtic peoples. This cultural and linguistic heterogeneity led the Romans to adopt different strategies to conquer and occupy the territory, which logically also had direct consequences on the speed and depth of the Latinization process, and one of its manifestations: the adoption of Latin names by the local population.

Although the Iberian language is still poorly understood, we have detailed knowledge of its personal naming system, thanks mainly to a Latin inscription found in Rome, the so called Ascoli Bronze or Turma Salluitana (CIL I $\left.{ }^{2} 709\right),{ }^{24}$ a document recording the grant of Roman citizenship to a series of equites from the Ebro Valley, most of whom were Iberian, as a reward for their collaboration in the Social War (see table 1 for the complete list of these names). This relatively long list of names allowed some conclusions to be drawn on the compositional rules of Iberian names, which later enabled the identification

\footnotetext{
${ }^{21}$ That is, the language transmitted by the inscriptions in the Southwestern script, probably dating from the fifth century B.c.

${ }^{22}$ The Turdetanian language can be identified in modern-day Andalusia, mainly through personal and place names transmitted by classical sources and Latin inscriptions. It is also possible that some of the Palaeohispanic inscriptions found in this area and lacking Iberian parallels belong to this language; cf. in fig. 1 "southern inscriptions of doubtful Iberianness." See Correa 2009; de Hoz 2010: 471-478; 2016; Ferrer 2017 and 2018.

${ }^{23}$ On Vasconic-Aquitanian literacy, see Velaza 2009.

${ }^{24}$ Criniti 1970
} 


\begin{tabular}{|c|c|}
\hline & Segienses \\
\hline Sanibelser Adingibas $f$. & Sosinaden Sosinasaef. \\
\hline Illurtibas Bilustibasf. & Sosimilus Sosinasaef. \\
\hline Estopeles Ordennasf. & Vrgidar Luspanarf. \\
\hline Torsinno Austinco $f$. & $\begin{array}{l}\text { Gurtarno Biurno } f \text {. } \\
\text { Elandus Enneges } f\end{array}$ \\
\hline Bagarensis & Agirnes Bennabelsf. \\
\hline Cacususin Chadarf. & $\begin{array}{l}\text { Nalbeaden Agerdo f. } \\
\text { Arranes Arbiscarf. }\end{array}$ \\
\hline $\begin{array}{l}\text { Jucenses } \\
\text { ] Sosimilusf. }\end{array}$ & Vmargibas Luspangibf. \\
\hline Jirsecelf. & Ennegenses \\
\hline Jelgaun $f$. & Beles Vmarbelesf. \\
\hline Jespaiser $f$. & $\begin{array}{l}\text { Turinnus Adimels } f \text {. } \\
\text { Ordumeles Burdo } f \text {. }\end{array}$ \\
\hline \multicolumn{2}{|l|}{ Ilerdenses } \\
\hline Q. Otacilius Suisetarten $f$. & Libenses \\
\hline $\begin{array}{l}\text { Cn. Cornelius Nesille f. } \\
\text { P. Fabius Enasaginf. }\end{array}$ & $\begin{array}{l}\text { Bastugitas Adimelsf. } \\
\text { Vmarillun Tarbantuf. }\end{array}$ \\
\hline Begensis & Suconsenses \\
\hline \multirow[t]{2}{*}{ Turtumelis Atanscer $f$. } & $\begin{array}{l}\text { Belennes Albennesf. } \\
\text { Atullo Tautindalsf. }\end{array}$ \\
\hline & $\begin{array}{l}\text { Illuersensis } \\
\text { Balciadin Balcibilf. }\end{array}$ \\
\hline
\end{tabular}

Table 1. Iberian names of the Turma Salluitana (Ascoli Bronze, CIL I² 709).

of Iberian anthroponomy in Latin epigraphy from Hispania and in vernacular inscriptions. $^{25}$

The available sources mentioning Iberian names are very rich, including local epigraphic documents (Iberian and Celtiberian), Latin and Greek inscriptions, and also some classical sources (fig. 2). The advantage of such wide-ranging documentation, spanning six centuries and several different writing systemsGreek, Latin, and various Palaeohispanic scripts-is that it provides a diachronic overview of the evolution of Iberian naming practices. It also enables us to describe contact phenomena between the different peninsular languages, and to precisely identify Iberian names in Latin epigraphy, without the use of vague labels such as "hapax" or "local name."

${ }^{25}$ For a survey on Iberian naming patterns, see Moncunill 2017. 
In the earliest evidence- the Greek and Iberian inscriptions dating from the late fifth century B.c. - the original Iberian naming formula seems very simple, with just a single name. With the Roman conquest, Iberian naming formulae became more complex, with the introduction of the patronymic, which was probably expressed in Iberian with two names in asyndeton usually followed by the word eban or ebanen, probably meaning filius (e.g., balkeatin isbetartiker ebanen [F.11.3], "Balceadin, son of Isbetartiger") and even sometimes with the origo, as, for instance, in the mosaic from Caminreal, which reads likinete ekiar usekerteku ("Likinos, from Osicerda, made it," K.5.3). ${ }^{26}$

\section{IBERIAN NAMES IN LATIN INSCRIPTIONS}

The available documentation in Latin epigraphy provides around 130 Iberian names ${ }^{27}$ found in sixty-two inscriptions, most of which are funerary, although we also find some instances on bronze plaques or instrumenta. It has been stated that Iberian names in the Latin epigraphic record are very rare due to the fast and effective Romanization of the Iberian territories, ${ }^{28}$ and it is, in fact, a small corpus, especially when compared to the several thousand Indo-European local names found in central Spain and along the Atlantic and Cantabrian coasts. ${ }^{29}$ Nevertheless the corpus includes more instances than previously thought, and allows us to put forward some hypotheses on the sociocultural implications of this phenomenon.

Apart from the long series of Iberian names in the Ascoli bronze, the rest of the occurrences are found in Latin inscriptions from Hispania, mainly from the Iberian linguistic area and its surroundings, as can be noted in the map in fig. $3{ }^{30}$ The comparison of the distribution area of Iberian personal names in

${ }^{26}$ On eban, see Velaza 1994; Velaza 2004; contra Untermann (1984) and Rodríguez Ramos (2001), who interpret it as the translation of coeravit and sustain that the filiation is just expressed in Iberian by the juxtaposition of two names, the son and the father, without any appellative. In this paper the Palaeohispanic inscriptions are quoted according to the Monumenta Linguarum Hispanicarum by J. Untermann (1990); for the inscriptions found after the publication of this work, the references are given according to the Hesperia database (http://hesperia.ucm.es/). The typographic conventions used to transcribe the Iberian languages are as follows: bold for texts written in Iberian non-dual script (neitinke), bold italics for texts in Iberian dual script (baidesbi) and italics for Graeco-Iberian texts (naltinge).

${ }^{27}$ The study of the indigenous onomastics from Hispania as transmitted in Latin epigraphy goes back to the works by Palomar (1957), Albertos (1966), and the cartographic study by Untermann (1965). However, there is not yet a specific study of Iberian names in Latin epigraphy: some of these names are compiled in Untermann 1990: 195-238; Rodríguez Ramos 2014; Faria 2000-18. The material and lists of names used for this article are the result of the work carried out for the onomastic sections of the Hesperia Database: http://hesperia.ucm.es/onomastica.php.

${ }^{28}$ See, for instance, Curchin 2004: 204.

${ }^{29} \mathrm{See}$, for a compilation of all these names, Vallejo 2016.

${ }^{30}$ An exceptional case might be the name Esdopleles in one inscription from Morocco (AE 1992, 1940); see Faria 2009: 161-162 and Bernard and Christol 2009: 195-196. 
Latin epigraphy with the distribution area of Iberian as a written language (cf. fig. 1) gives rise to a few observations:

1. First of all, the lack of Iberian names in Narbonensis and their lower density along the Catalan coast is surprising if we consider the fact that other types of sources (e.g., the indigenous sources and also some Greek inscriptions) abundantly record Iberian names in these areas (see fig. 2).

2. The situation is different around the area of Saguntum, where Iberian names in Latin inscriptions are more numerous.

3. Further south, in Ulterior, we also find a good number of instances, Castulo being the most important centre.

4. Finally, it is worth noting the penetration of Latin inscriptions bearing Iberian names in other linguistic areas, beyond the Iberian core, in the Celtiberian, Vasconic and Turdetanian regions, which can probably be explained by a greater mobility of the population in the Roman period.

Regarding this last point, it is worth pointing out that, in these peripheral areas, Iberian names written in Latin sometimes display graphic oddities, such as the use of aspirated or affricate consonants that do not exist in Iberian, which is probably due to contact with other local languages: for instance, Urchatetel (instead of *Urcatetel), where the graphemes $-\mathrm{CH}$ - seem to express an aspiration, or Ordunetsi (instead of *Ordunesi), with a fricative sound expressed as -TS-; since these two instances come from the Vasconic territory and Basque does present these kinds of sounds, a plausible explanation is that these Iberian names were Latinized by speakers of other local languages. In other cases, the displacement of Iberian anthroponomics from their original area creates hybrid naming formulae, as recently studied in the case of the stela from Illescas, in Toledo. ${ }^{31}$ In this inscription, the patronymic Benilti, an Iberian name, is followed by the name of the family expressed in the genitive plural, Aeturiqum-following the indigenous declension - as is common in Hispano-Celtic onomastics, but not in the Iberian tradition (Hep 4, 889): ${ }^{32}$

Ammisa $\cdot$ Benil/tì Aeturiq(um) $\cdot$ f(ilia) $) /$ Clouti $\cdot$ Maure/icum $\cdot u x(o r) \cdot / b(i c) \cdot s(i t a) \cdot e(s t)$

It is interesting to note, therefore, how the pre-Roman linguistic areas became somewhat blurred as the use of Latin progressed in Hispania.

As for the general chronology of Latin inscriptions mentioning Iberian names, they span from the late second century B.c. to the beginning of the second century A.D., with most instances belonging to the first century A.D. As can be seen in fig. 4, cases from the republican period are not particularly abundant and, during this time, these documents are almost exclusively located in Hispania Ulterior. During the first centuries of Roman rule, Iberian names were, of

${ }^{31}$ Luján 2013: 126; Simón 2015. 2014.

${ }^{32}$ For the different naming patterns among the indigenous communities of Hispania, see Luján 
course, also used in Citerior, but in this province they are mostly found in inscriptions in Iberian (fig. 5). As a matter of fact, these Iberian republican inscriptions from Hispania Citerior display the clear influence of the Roman epigraphic habit, not just judging from the ordinatio and technical execution of the inscription, but also from the content of the text. ${ }^{33}$ A very clear case can be seen in fig. 5.1, an Iberian monumental inscription from the forum of Empúries mentioning an individual named Cornelius. The other images in fig. 5 also show the evolution of the indigenous epigraphic habit: from the still clearly local manifestations, such as the stela from Binéfar (fig. 5.2), in which the heroic iconography of indigenous resonance still occupies a preferential place, to the perfect adaptation to the Latin model, as shown by the bilingual inscriptions of Saguntum and Tarraco (figs. 5.3 and 5.4).

The linguistic identity of the elite was therefore expressed differently in the two provinces during the first centuries of Roman rule: even in important centres of Citerior such as Emporiae, Tarraco, or Saguntum, where there was probably a significant Italian presence, the local inhabitants continued to express themselves almost exclusively in Iberian during the republican period-even, in some cases, after adopting Latin nomina - whereas further south they were already using Latin. From the Augustan period onwards this situation changed.

\section{SOME REMARKS ON THE LATINIZATION OF IBERIAN NAMES}

Iberian names written in Latin provide valuable linguistic information, which can be used both for a better understanding of Iberian phonetics and to assess the different adaptation processes of foreign names into Latin. I will mention here a few illustrative examples.

The Latin spelling of these names reveals phonetic phenomena that reflect movement in two directions. In the first place, some sounds which might have seemed odd to a Latin speaker are rendered in a way that seems natural from the perspective of Latin phonology: for instance, the Iberian diphthong -ai- is quite systematically adapted as -ae- in the Latin transcriptions (e.g., Sosinasae instead of *Sosinasai, or Salaeco instead of *Salaico). In the second, we can also observe many phonetic contact phenomena that reveal a straightforward phonetic transcription, with a large number of assimilations (e.g., Balciadin, instead of balke adin [as attested in Iberian script in $M L H$ F.11.11 and 12] or Cacususin instead of *Cacusosin). These renderings are especially frequent in the Ascoli Bronze, a text written in Rome, probably by a non-Iberian speaker, but in inscriptions from Hispania the adaptation of Iberian names can be slightly different, as I will explain below.

Some other graphic conventions adopted in the Ascoli Bronze are also significant. The secondary contact of some sounds, for instance $[\mathrm{n}]$ and $[\mathrm{b}]$, found

\footnotetext{
${ }^{33}$ For the epigraphic habit in the local languages of Hispania, see Mayer and Velaza 1993; Beltrán 2012; and, more recently, Simón 2013a: 21-294.
} 
on a morphological frontier, is systematically assimilated, in this particular case into [m]: thus, ordin bels becomes Ordimels, sosin.bilos, Sosimilus, and so on. ${ }^{34}$ In Latin inscriptions from Hispania these two sounds can also be rendered -m-, but this solution is not systematically adopted: we find, for instance, Sosimilos (BDH Onom.4185) for the name *sosin-bilos, as in the Ascoli Bronze, but also transcriptions which respect the original spelling, for instance Neitinbeles (BDH Onom.3315) and not *Neitimeles, in one inscription from Terrassa dated to the Augustan Age (CIL II 6144). The same happens with the Iberian digraph $-1 \mathrm{~d}-,{ }^{35}$ which is systematically transliterated as a double $\mathrm{L}$ or just $\mathrm{L}$ in the Ascoli Bronze: for instance, the Iberian name of Zaragoza, Salduie, as found in the local coin legends, will give Turma Salluitana in Latin. But, again, in Latin inscriptions from Spain this rendering is not systematic: the group -ldis sometimes adapted also as -11- or -1- (e.g., Bodonilur [BDH Onom.1393], instead of ${ }^{*}$ Bodonildur), but in some other cases the Latin transcription just follows the original spelling, the same one that we find in the epichoric script: for example, Ildi(r) and not Illi(r); ${ }^{36}$ Galduriaunin and not Galluriaunin; ${ }^{37}$ Adinildir and Erdoild[ir instead of Adinillir and Erdoillir. ${ }^{38}$

These different treatments might imply a different level of familiarity with the Iberian language and script: in some cases, the person who was writing does not seem to have been aware of the graphic conventions used in the Palaeohispanic writing systems, and probably not even of the original meaning lying behind these names, while in other cases the local graphic conventions still seem to be present. Such phenomena give us indirect clues about whether Iberian was still written and spoken at a time when it is not directly attested; moreover, it also provides us with direct evidence that these Latin texts were indeed written by local people.

Regarding the grammatical adaptation of Iberian names to Latin declension, Hugo Schuchardt (1909: 239), in one of the first studies on the Ascoli Bronze, had already noticed that in this document Iberian names are not inflected: for instance, Beles Vmarbelesf(ilius), with no genitive mark for the patronymic. The same occurs in the Second Bronze from Botorrita, the so-called Tabula Contrebiensis ( $A E$ 1979, 377), where, unlike Celtiberian names, which are declined, the Iberian names present no declensions: Turibas Teitabas filius. The same applies to the only Vasconic name mentioned in the bronze: Jassius +eibar f.

\footnotetext{
${ }^{34}$ It is plausible that -nb- was actually pronounced [m] in Iberian: in two stamps from Azaila, one in Latin (Protemus fecit [ELRH SC19]), the other in Iberian (boŕotenbotenin [MLH E.1.287]), which seem to be equivalent in content (see Vallejo 1943: 474-475 and Estarán 2016: 344), the name "Protemus," in the Latin text, was written boŕotenbo in Iberian, where -nb- would also stand for $\mathrm{m}$.

${ }^{35}$ See recently Simón and Jordán 2014.

${ }^{36}$ Simón and Jordán 2014

${ }^{37} \mathrm{BDH}$ Onom.2569.

${ }^{38}$ Ferrer, Velaza, and Olesti 2018.
} 
It has been suggested that this could be due to the fact that Indo-European names are easier to adapt to Latin grammar than Iberian or Vasconic ones. ${ }^{39}$ Although this could indeed be the reason, it is also worth noting that the exact same structure is found in Iberian inscriptions-mainly in funerary texts dating from the second century в.c. onwards-where the filiation seems to be expressed with two names in asyndeton, with no morphological mark. Another example in which names appear in simple parataxis is that of the recently published inscription mentioning the quattuorviri of Iulia Lybica:

Bella $\cdot$ Gaisco $\cdot f($ ilius $) /$ Bella $\cdot$ Bastobles $\cdot f($ ilius $) /$ Adinildir $\cdot$ Betepe $[-\cdot f($ ilius $)] /$ Corneli . Erdoild[ir $\cdot f($ ilius $)] /$ scriptum $\cdot$ est $\cdot$ IIII $\cdot$ viratum. ${ }^{40}$

As the editors propose, the most feasible interpretation of this rock-face inscription found in the Pyrenees is that the scribe still had a very poor knowledge of the Latin language.

I see two possible ways to explain why these Iberian names were not adapted to Latin morphology. One is that the scribe did not bother to make the metalinguistic effort to accommodate them to Latin morphology, which seems a reasonable explanation for what happened in the Ascoli Bronze or in the Tabula Contrebiensis from Botorrita- both documents being issued by Roman authorities. Alternatively, the scribe just respected the original Iberian onomastic conventions in a proper case of code-switching, which appears plausible, in turn, for the rock inscription from the Pyrenees, written in an indigenous context, probably by someone whose mother tongue was not Latin. ${ }^{41}$

In the remaining Latin inscriptions from Hispania, however, Iberian names are generally adapted to Latin syntax, most often following the 3rd declension. This is not always perceptible in the nominative, but the inflection of the oblique cases is very clear and systematic: for instance, Tascasecer becomes Tascasecer-is in the genitive, Asterdumar becomes Asterdumar- $i$ in the dative, Toloco becomes Toloco- $n$-is in the the genitive, and so on (see table 2). This could be taken as evidence that the use of Latin was becoming more widespread amongst Iberian name bearers. It is also relevant that most inflected names are later than the non-inflected ones, and that the few cases of inflected names belonging to the republican period mostly come from Ulterior, where the Romanization process is believed to have been intense from a very early stage. It seems then possible to consider the declension of Iberian names in Latin as linked to the advance of the Latinization process and the adoption of Latin as a vehicular language by local inhabitants.

${ }^{39}$ Gorrochategui 2011: 77; Estarán 2016: 367.

${ }^{40}$ Ferrer, Velaza, and Olesti 2018.

${ }^{41}$ Adams (2003: 369) makes an important point: "The name is such an inseparable part of a person's identity that it may retain its grammatical characteristics when it is transferred into another language." In some cases, the author considers that this might entail linguistic retention (379). 


\begin{tabular}{llll}
\hline & 3rd declension & & 2nd declension \\
\hline Tascasecer-is & Vrchatetell $-i$ & Agirsar-is & Agirsen- $i$ \\
Arancis-is & Asterdumar- $i$ & Baesiscer - is & Agirsen- $i-0$ \\
Bastogaunin- $i$ & Istamiur - is & Laceril-is & Benilt $-i$ \\
Ordunets $-i$ & Tannepaeser- $i$ & Tannegaldun-is & Turinnus \\
Tannegiscerr-is & Toloco- $n$ - - is & & \\
\hline
\end{tabular}

Table 2: The inflection of Iberian names in Latin

These are just a few examples, among many others, illustrating how the adaptation of Iberian names into Latin gives us valuable linguistic data. But, beyond its interest from a linguistic point of view, this documentation is also relevant for social and cultural history. To explore this second dimension in greater depth, in the following sections the corpus will be considered, on the one hand, on the basis of the level of the Romanization of the onomastic formula, and, on the other, of the inscriptions' epigraphic material, typology, chronology and provenance.

\section{TAXONOMY OF THE LATIN ONOMASTIC FORMULAE CONTAINING}

IBERIAN NAMES

In this section the catalogue of names is organized on the basis of the different naming structures. I will begin by discussing the nomina unica, used either by peregrini or slaves, and then I will focus on structures with duo or tria nomina, borne by individuals of higher status. ${ }^{42}$

\section{Single names: peregrini and slaves}

If we leave aside the Ascoli Bronze and focus exclusively on inscriptions from Hispania, a relatively small portion of individuals attested in the corpus were peregrini or slaves: that is, people without a nomen (around 30\% of the total). This proportion of non-citizens is even lower than the total of individuals bearing peregrine nomenclature in J. M. Abascal's (1994: 27) comprehensive compilation of names from Hispania, in which $38.01 \%$ of individuals do not bear a Latin nomen. These inscriptions featuring Iberian name bearers therefore follow the same general trend as the rest of Latin inscriptions from Hispania, but in an even more pronounced way, in the sense that the upper classes are much better

\footnotetext{
${ }^{42}$ This catalogue is comprehensive, though some doubtful readings or very fragmentarily preserved inscriptions have not been included in the structural analysis of the onomastic formulae. They concern the following instances: Acirsenio and Curtaanbasis (HEp. 3, 268); Jaurc(i)d(i)r (Faria 2016: 166); Belestice and Iscaniuse (CILA III 1, 216, see also above, 145, n. 36); Caribelo (AE 1984, 597); Coniagellietar (IRC II, 12); Irurciradin or Turciradin (CIL II 2976); ]nnadisc[-]r (Hep 14, 138); Jresunin (HEp 12, 492); Sosinaibole (HEp 12, 447); Sosumilus (EE 9 358; cf. for the correct reading HEpOl 18426); Vrchail (ELRH U28).
} 
represented than the lower classes. Names in this section are organized in the following tables:

Table 3: This table contains cases with the simplest naming formula, consisting of a single Iberian name with no further information. Among the few available examples of this nomenclature, two are women (nos. 1 and 2) and the others (no. 3, 4, and 5) are names found on instrumenta.

Table 4: This table contains cases where the local idionym is followed by the patronymic, which is always an Iberian name, (e.g., in no. 6: Socedeiaunin Istamiuris filia). In general terms, it is worth highlighting that intergenerational changes always take place in the expected direction: in this particular set, the parents of Iberian name bearers also carry Iberian names. Case no. 10, however, is peculiar, since it displays, as explained in section 4, a syncretic formula, half-Celtic, half-Iberian, whose structure is: Celtic name + Iberian patronymic + Celtic family name (Ammisa Benilti Aeturiq(um) f(ilia)), which can probably be explained by the fact that the inscription comes from outside Iberian territory. Occasionally the name is also followed by the origo, as happens for no. 9: Vrcestar Tascaseceris f(ilius) Ilurconensis. The mention of the place of origin, which could work in certain cases as an identity marker, is quite unusual in the context of the corpus as a whole: apart from this case, there are only three more attestations (no. 15, Otobesanus; no. 44, Bacasitanus, and maybe no. 36, [La]cetanus?). Note that all are Iberian place names adapted to Latin, although their precise location is sometimes uncertain and does not necessarily match the findspot of the inscription.

Table 5: The cases displayed in this table are especially interesting from a sociolinguistic point of view. The table brings together names of some peregrini who bear an individual name in Latin, while their parents bore an Iberian name (e.g., in no. 15, Seranus Tannegiscerris f(ilius)), in what seems to betray a wish to Latinize one's nomenclature even among those who do not seem to have experienced an official change in their social status.

Table 6: Finally, among these people without a nomen, we also find a couple of slaves. Although it was the belief of scholars that slaves did not bear Iberian names, ${ }^{43}$ these examples, together with the following set of freedmen (table 7), show that this group could also use Iberian anthroponomy. In any case, mentions of slaves and freedmen remain relatively scarce in this corpus.

\section{Structures with Latin nomina and Iberian cognomina}

As expected, the number of individuals attested with a nomen, an element associated with Roman citizenship, is higher than that of the peregrini. This is not surprising, considering the intrinsic characteristics of these inscriptions, which are mostly found on stone: having the opportunity to engrave one's name on a publicly displayed inscription and choosing the Latin language to do so are by themselves evidence of the process of Romanization. It might be interesting

${ }^{43}$ See, for instance, de Hoz 2011: 333. 


\begin{tabular}{|c|c|c|c|c|c|}
\hline$\overline{\text { No. }}$ & Name & Published & Date & Inscription & Provenance \\
\hline 1 & $\begin{array}{l}\text { Asterdumari } \\
\text { matri (dat.) }\end{array}$ & CIL II 5840 & $\begin{array}{l}\text { 1c. B.C.- } \\
\text { 1c. A.D. }\end{array}$ & funerary & Obarra, Huesca \\
\hline 2 & Asteduma & CIL II 14, 274 & 1c. A.D. & funerary & $\begin{array}{l}\text { Algimia de Almonacid, } \\
\text { Castellón }\end{array}$ \\
\hline 3 & Tanniber & Simón 2014 & $\begin{array}{l}\text { 1c. B.C.- } \\
\text { 1c. A.D. }\end{array}$ & $\begin{array}{l}\text { stamp on } \\
\text { lead ingot }\end{array}$ & $\begin{array}{l}\text { Cabrera wreck, coming } \\
\text { from Baetica }\end{array}$ \\
\hline 4 & Vnibel & $H E p$ 7, 300 & $\begin{array}{l}\text { end of the } \\
\text { Republic }\end{array}$ & $\begin{array}{l}\text { graffito on } \\
\text { slate plate }\end{array}$ & $\begin{array}{l}\text { Villanueva del Duque, } \\
\text { Córdoba }\end{array}$ \\
\hline 5 & Ildi & $\begin{array}{l}\text { Simón-Jordán } \\
2014\end{array}$ & 2c.-1с. в.с. & $\begin{array}{l}\text { graffito on } \\
\text { pottery }\end{array}$ & $\begin{array}{l}\text { Alcudia de Elche, } \\
\text { Alicante }\end{array}$ \\
\hline
\end{tabular}

Table 3: Iberian individual name

\begin{tabular}{|c|c|c|c|c|c|}
\hline No. & Name & Published & Date & Inscription & Provenance \\
\hline 6 & $\begin{array}{l}\text { Socedeiaunin } \\
\text { Istamiuris filia }\end{array}$ & $E E 8,239$ & 1с. в.с. & funerary & Castulo, Jaén \\
\hline 7 & $\begin{array}{l}\text { Ausages Agirn [is } \\
\text { f(ilius?)] }\end{array}$ & $H E p 2,735$ & 1c. A.D.? & funerary & $\begin{array}{l}\text { Artieda, Zara- } \\
\text { goza }\end{array}$ \\
\hline 8 & $\begin{array}{l}\text { Turibas Teitabas } \\
\text { filius }\end{array}$ & $\begin{array}{l}A E 1979,377 \\
E L R H \text { C9 }\end{array}$ & 87 в.с. & $\begin{array}{l}\text { Botorrita } \\
\text { bronze plaque }\end{array}$ & $\begin{array}{l}\text { Botorrita, } \\
\text { Zaragoza }\end{array}$ \\
\hline 9 & $\begin{array}{l}\text { Vrcestar Tasca- } \\
\text { seceris f(ilius) } \\
\text { Illurconensis }\end{array}$ & $\begin{array}{l}C I L \text { II 2067; } \\
E L R H \text { U50 }\end{array}$ & 1с. в.с. & funerary & $\begin{array}{l}\text { Cerro de los } \\
\text { Infantes, Pinos } \\
\text { Puente, Granada }\end{array}$ \\
\hline 10 & $\begin{array}{l}\text { Ammisa Beniltì } \\
\text { Aeturiq(um)f(ilia) }\end{array}$ & $H E p$ 4, 889 & 1c. A.D. & fune & Illescas, Toledo \\
\hline 11 & $\begin{array}{l}\text { Bella Gaisco } \\
\text { f(ilius) }\end{array}$ & $\begin{array}{l}\text { Ferrer-Velaza- } \\
\text { Olesti } 2018\end{array}$ & Augustan & $\begin{array}{l}\text { rock } \\
\text { inscription }\end{array}$ & $\begin{array}{l}\text { Oceja, Pyrénées- } \\
\text { Orientales }\end{array}$ \\
\hline 12 & $\begin{array}{l}\text { Bella Bastobles } \\
\text { f(ilius) }\end{array}$ & $\begin{array}{l}\text { Ferrer-Velaza- } \\
\text { Olesti } 2018\end{array}$ & Augustan & $\begin{array}{l}\text { rock } \\
\text { inscription }\end{array}$ & $\begin{array}{l}\text { Oceja, Pyrénées- } \\
\text { Orientales }\end{array}$ \\
\hline 13 & $\begin{array}{l}\text { Adinildir Betepe[ } \\
\text { f(ilius) }\end{array}$ & $\begin{array}{l}\text { Ferrer-Velaza- } \\
\text { Olesti } 2018\end{array}$ & Augustan & $\begin{array}{l}\text { rock } \\
\text { inscription }\end{array}$ & $\begin{array}{l}\text { Oceja, Pyrénées- } \\
\text { Orientales }\end{array}$ \\
\hline
\end{tabular}

Table 4: Iberian/local individual name + Iberian patronymic + (origo)

\begin{tabular}{llllll}
\hline No. & Name & Published & Date & Inscription & Provenance \\
\hline 14 & $\begin{array}{l}\text { Nigrinus Belsunis } \\
\text { flius }\end{array}$ & AE 2013,912 & 1c. A.D. & funerary & $\begin{array}{l}\text { Alcaraz, } \\
\text { Albacete }\end{array}$ \\
15 & $\begin{array}{l}\text { Seranus Tannegis- } \\
\text { cerris f(ilius) } \\
\text { Otobesanu[s] }\end{array}$ & CIL II 3794 & 1c. A.D. & funerary & $\begin{array}{l}\text { Llíria, València } \\
\text { València }\end{array}$ \\
16 & $\begin{array}{l}\text { Faustus Astlumis } \\
\text { f(ilius) }\end{array}$ & HEpOl 70 & 1c. A.D.? & funerary & Villaricos, \\
\hline
\end{tabular}

Table 5: Latin nomen unicum + Iberian patronymic + (origo) 


\begin{tabular}{llllll}
\hline No. & Name & Published & Date & Inscription & Provenance \\
\hline 17 & Sanib[-- ] ser(vus) & CILA Jaén, 153 & 1c. A.D. & funerary & Castulo, Jaén \\
18 & $\begin{array}{l}\text { Acerd(o?) } \text { ? }^{44} \text { Sapo(ni) } \\
\text { CIL II 5927; }\end{array}$ & 2c.-1c. B.c. & building & Cartagena, \\
& M(arci)s(ervus) & ELRH C10 & & inscription & Murcia \\
\hline
\end{tabular}

Table 6: Iberian individual name + name of the owner + servus

to compare this situation with what can be observed in other areas of the Roman world. In the case of Britain, for instance, which has been studied by Mullen (2007), the percentage of people bearing Celtic names who also bear a nomen gentilicium is strikingly low (only $6 \%$ of the total bear duo nomina, and under $2 \%$ bear tria nomina). There are two remarkable differences between these two corpora that might explain these different behaviours. In the first place, Celtic names in Britain are mostly found on instrumenta or writing tablets, whereas the corpus from Hispania mainly comes from funerary inscriptions on stoneand obviously the writing material itself has to be considered not just as a determining factor of the text but also as a hint of cultural appropriation, if not assimilation. Secondly, it is important to keep in mind that epigraphic practices in the Iberian Peninsula were not limited to Latin, which means that the local inhabitants could still choose to use their own languages and scripts for everyday life purposes. What this seems to confirm, in any case, is that the inscriptions in this section must be seen as testimony of an advanced process of Romanization among Iberians.

Let us now turn to the concrete structures of these individuals with a Latin nomen. In the following tables (7 to 12) the names are organized as follows:

Table 7: liberti with an Iberian cognomen. Mentions of freedmen and freedwomen are slightly more abundant than mentions of slaves, but still not very high; interestingly, this group includes a high proportion of references to women (thee out of four cases). Note as well that all the slaves and liberti with Iberian names attested so far are found in the southern half of the territory, although what we can infer from this, given the small numbers involved, is not clear.

Tables 8 and $9:^{45}$ cases of tria nomina with Iberian cognomina. With respect to other social groups, in most cases the onomastic formula is articulated as tria nomina, with no further information (table 8), for example, in no. 25: M(arcus) Licinius Neitinbeles. In other cases (table 9), the name of the father is also specified and, hereafter, often also the tribus: for example, in no. 34: $M$ (arcus) Horatius M(arci) f(ilius) Gal(eria) Bodonilur; mention of the origo is, as stated earlier, less common. Regarding the patronymic, it is important to note that

\footnotetext{
${ }^{44}$ Perhaps doubtful, as Rodríguez Ramos (2014: 107) points out that it comes in a long list of non-Iberian names. The linguistic analysis is, however, compatible with it being Iberian.

${ }^{45}$ In table 8 I exclude $P$ (ublius) Bae(bius) Sosum [i]lus (EE 9 358) from the list because this reading is mistaken; see $H E P O l 18426$.
} 


\begin{tabular}{|c|c|c|c|c|c|}
\hline No. & Name & Published & Date & Inscription & Provenance \\
\hline 19 & $\begin{array}{l}\text { Baebia Cn(aei) } \\
\text { l(iberta) } \\
\text { Tavaccalaur }\end{array}$ & $\begin{array}{l}\text { CIL II } \mathrm{II}^{2} 15 \\
427\end{array}$ & 1c. B.C. -1c. A.D. & funerary & $\begin{array}{l}\text { Sagunt, } \\
\text { València }\end{array}$ \\
\hline 20 & $\begin{array}{l}\text { Fabia L(uci) } \\
\text { l(iberta) Vnini[- - ] }\end{array}$ & CIL $\mathrm{II}^{2} / 7,11$ & 1c.-2c. A.D. & funerary & Jimena, Jaén \\
\hline 21 & $\begin{array}{l}\text { Publicia m(unicipii) } \\
\text { S(aguntinourm) } \\
\text { l(iberta) Agirtilla }\end{array}$ & $\begin{array}{l}\text { CIL II } \mathrm{II}^{2} 14 \\
378\end{array}$ & 1c. A.D. & funerary & $\begin{array}{l}\text { Sagunt, } \\
\text { València }\end{array}$ \\
\hline 22 & $\begin{array}{l}\text { Cn(aeus) Atellius } \\
\text { Cn (aei) (libertus) } \\
\text { Toloco }{ }^{46}\end{array}$ & CIL II 3450 & 1c. A.D. & funerary & $\begin{array}{l}\text { Cartagena, } \\
\text { Murcia }\end{array}$ \\
\hline
\end{tabular}

Table 7: (Praenomen $)+$ nomen + name of the former owner + Iberian cognomen

\begin{tabular}{|c|c|c|c|c|c|}
\hline No. & Name & Published & Date & Inscription & Provenance \\
\hline 23 & $\begin{array}{l}\text { L(ucius) Cor- } \\
\text { (nelius) Sosimilos }\end{array}$ & CIL II 3295 & $\begin{array}{l}\text { beginning of } \\
\text { the principate }\end{array}$ & funerary & Casulo, Jaén \\
\hline 24 & $\begin{array}{l}M \text { (arcus) Porcius } \\
\text { Escerior }\end{array}$ & CIL II 3988 & 1c. A.D. & funerary & $\begin{array}{l}\text { Vilanova de la } \\
\text { Reina, Castelló }\end{array}$ \\
\hline 25 & $\begin{array}{l}M \text { (arcus) Licinius } \\
\text { Neitinbeles }\end{array}$ & CIL II 6144 & 30 в.с. - A.D. 14 & funerary & $\begin{array}{l}\text { Terrassa, Bar- } \\
\text { celona }\end{array}$ \\
\hline 26 & $\begin{array}{l}L(\text { ucius) Iuni(us) } \\
\text { Bil(---) }\end{array}$ & ELRH U57 & 30 в.C. - A.D. 50 & votive & $\begin{array}{l}\text { Córdoba } \\
\text { area }\end{array}$ \\
\hline 27 & $\begin{array}{l}\text { L(ucius) Silius } \\
\text { Toloco }\end{array}$ & $H E p$ 15, 368 & 1st-2nd c. A.D. & $\begin{array}{l}\text { dedication to } \\
\text { Mercurius }\end{array}$ & $\begin{array}{l}\text { Monreal de } \\
\text { Ariza, } \\
\text { Zaragoza }\end{array}$ \\
\hline 28 & $\begin{array}{l}\text { L(ucius) Innius } \\
\text { Laurbeles }\end{array}$ & $I R C$ II 83 & 1c. A.D. & funerary & $\begin{array}{l}\text { Florejacs, } \\
\text { Lleida }\end{array}$ \\
\hline 29 & $\begin{array}{l}\text { L(ucius) Aemiliu[s] } \\
\text { Tartigar [- - - }\end{array}$ & $\begin{array}{l}A E \text { 1981, } \\
582\end{array}$ & 1c. A.D. & funerary & $\begin{array}{l}\text { Sagunt, Valèn- } \\
\text { cia }\end{array}$ \\
\hline 30 & $\begin{array}{l}\text { P(ubli) Baebi } \\
\text { Baesisceris(Gen.) }\end{array}$ & CIL II 3221 & 2c. A.D. & $\begin{array}{l}\text { building } \\
\text { inscription }\end{array}$ & $\begin{array}{l}\text { Granátula de } \\
\text { Calatrava, } \\
\text { Ciudad Real }\end{array}$ \\
\hline 31 & $\begin{array}{l}C(\text { aius }) \text { Licinius } \\
\text { Adin }\end{array}$ & Simón 2018 & 1c. A.D. & $\begin{array}{l}\text { stamp on } \\
\text { pottery }\end{array}$ & $\begin{array}{l}\text { Can Pedrerol, } \\
\text { Barcelona }\end{array}$ \\
\hline
\end{tabular}

Table 8: Praenomen + nomen + Iberian cognomen

the father is always mentioned here by a Latin praenomen, which is indicative instead of an Iberian name, ${ }^{47}$ of the generational changes that might have oc-

\footnotetext{
${ }^{46}$ For this restitution, see Abascal and Ramallo 1997: 248-250.

${ }^{47}$ A special case could be CILA III 1, 216 (Au(li) [Cor]nel(i) Belesticef(ilii) and P(ublii) Corneli(i) Iscaniuse f(ilii)), where Rodríguez Ramos (2010) identifies the reminiscences of an indigenous de-
} 
curred in the choice of names. The presence of an Iberian cognomen is usually considered to entail a recent grant of Roman citizenship, but the fact that the father already bore tria nomina, as can be seen in these examples, suggests that this was at least the second generation of citizens and that the vernacular name was not necessarily abandoned immediately.

Table 10: cases of duo nomina with Iberian cognomen. The cases of duo nomina with an Iberian cognomen are much scarcer than the tria nomina, and, in the available cases, the filiation is never expressed.

Table 11: cases of fully Latin duo or tria nomina with Iberian patronymic. Unlike the previous groups, the set of individuals in this table display a fully Latinized name with a Latin cognomen, and only their patronymic is Iberian, which would suggest that the first generation of Roman citizens had already lost their vernacular name. Note that among them there is also a woman, in no. 42: Calpurnia Severa Tannegaldunis f(ilia). This case is remarkable, since it would imply that Calpurnia Severa had acquired Roman citizenship independently from her father, who bore a peregrine name. Without ruling out the possibility that she had acquired this status through her husband, one should also consider that the father's full name would have been *[Praenomen] Calpurnius Tannegaldunthough the usual way of expressing the patronymic in this case would have been the praenomen, not the cognomen.

Table 12: cases of women with Latin nomen and Iberian cognomen. Sometimes, the name of the father-always a Roman citizen, unlike in no. 42 above-is also mentioned, and even the name of the husband, as in no. 59, Corneliae L(uci) f(iliae) Sillibori Vetuli, one of the few honorific inscriptions in this corpus; on other occasions, however, women are mentioned without any filiation: for instance, Aelia Belesiar (no. 50). This is one of the rare cases in which an Iberian god, Betatun, is mentioned, ${ }^{48}$ instead of a Roman divinity, as in nos. 27 and 38, dedicated to Mercurius and Jupiter respectively. In the other cases of Iberian divinities known in Latin epigraphy, the dedicators bear fully Latin nomenclature: this is the case of the dedication to the god Salaeco (HEp 19, 2010, 218) ${ }^{49}$ by two freedmen in Cartagena (first century B.c.), and of the dedication to Sertundo (HEp 1, 1989, 346) ${ }^{50}$ by two peregrini, Campanus and Maximus, in Susqueda (Barcelona, second century A.D.). This complex mesh of correlations between names and other social and cultural aspects, such as religious devotion, is indicative of the multiple layers that could configure one's identity in this phase of formation of provincial society, when important features of the indigenous culture were still clearly alive. The remaining attestations come from funerary inscriptions. Among them no. 57, dating from the first century A.D., is particu-

clension in -e; note, however, that the inscription is only known by manuscript transmission and the reading is highly uncertain.

${ }^{48}$ Corzo et al. 2007.

${ }^{49}$ Velaza 2015.

${ }^{50}$ Vidal 2016: $196-200$. 
larly remarkable because it contains a carmen epigraphicum, ${ }^{51}$ and shows a perfect mastery of the Latin language and its poetic conventions, thus revealing a high degree of Latinization..$^{5}$

Looking at all the different tables and inscriptions in the aggregate, one notes that most of the inscriptions are funerary, a medium which might not have been affordable for everyone, but which also did not constitute the most prestigious medium of self-representation. As it is the most common epigraphic type all over the Roman world, ${ }^{53}$ its abundance is not surprising, and it is a medium of expression in which the admixture of the local tradition and Roman culture is particularly prominent. ${ }^{54}$

Aside from a relatively small number of peregrini and slaves, most of these Iberian name bearers have duo or tria nomina, with a Latin nomen and an Iberian cognomen, which gives us first-hand evidence of the impact of the juridical promotion of local inhabitants on their naming practices and the progressive abandonment of Iberian onomastics. This can also be taken as a sign that Latin had become at this point a language of prestige and power, which might have been one of the most important incentives of Latinization. However, the fact that only a very few of these citizens with Iberian cognomina are described as magistrates (nos. 11, 12, 13, and 47; 34 and maybe also 36$)^{55}$ suggests that the perpetuation of civic power in the hands of the local elites was not widespread. ${ }^{56}$ Yet absence of evidence cannot always be taken as evidence of absence, not only because of the intrinsic limitations of ancient onomastics, but also because some of the cases analysed here positively show that the first generation of citizens could already have given up Iberian nomenclature (see table 11). In this case the autochthonous origin of these individuals would only be recognisable through the name of the father, information which was not systematically mentioned

\footnotetext{
${ }^{51}$ The whole inscription reads: Cornelia L(uci)f(ilia) / Sirasteiun / hic sita est Sodalis amor rapuisti/ me nunc sumus una / dum vixsimus (sic) [se]mper con/[c] ordes nunc sumus certe pares / [tre]s et viginti annos aetas / [-- $]$ s nostra teneret/ $[---]$ fui semper/ $[---] R A E R[---s]$ ubito/ $[---] R /[---------$ $-] /[---] A C /[---] M E /[---]$.

${ }^{52}$ Díaz Ariño forthcoming.

${ }^{53}$ Beltrán 2015: 95.

${ }^{54}$ Cooley 2012: 143

${ }^{55}$ The full text of these inscriptions is: Bella $\cdot$ Gaisco $\cdot f($ ilius $) /$ Bella $\cdot$ Bastobles $\cdot f($ ilius $) /$ Adinildir - Betepe[- $\cdot f($ ilius $)] /$ Corneli $\cdot$ Erdoild[ir $\cdot f($ ilius $)] /$ scriptum $\cdot$ est $\cdot$ IIII · viratum (Ferrer, Velaza, and Olesti 2018); M(arcus) Horatius M(arci)f(ilius) / Gal(eria) Bodonilur / IIvir Lucretia L(uci) f(ilia) / Sergieton uxor (CIL II 2114) and [- S]ulpicio L(uci) f(ilio) Gal(eria) Ennagael[i La]cetano(?) / [ex] opp[ido Iessone(?)] qui [s]ub Do[m]itiano/[e]merit[us est---] con/[f]ectis o[mnibus(?) ---] quilesc[it(?) - - ] suis / [- - ] Sulpi[cio Ennagael(?) II]vi[r(o) f]lami[n]i / [Se]ve[- - - A] amin[i]/[ca(?) - - -]VM/ [---coniu]gi et /[sibi---f]ecit/[---an(norum)] LVIII (HEp 18, 452).

${ }^{56}$ Note, however, the mention of some Iberian magistrates in coin legends written in the Iberian language and script and another set of coin magistrates from Obulco (Porcuna, Jaén) whose name, written in Latin, is clearly indigenous but belongs to a language other than Iberian (probably Turdetanian, according to Correa 2009: 279-292). For the indigenous magistrates in Hispania, see Curchin 1990: 86-89.
} 


\begin{tabular}{|c|c|c|c|c|c|}
\hline$\overline{\text { No. }}$ & Name & Published & Date & Inscription & Provenance \\
\hline$\overline{32}$ & $\begin{array}{l}L \text { (ucius) Horatius } \\
M \text { (arci) f(ilius) } \\
\text { Viseradin }\end{array}$ & CIL II 4450 & & funerary & Sinarcas, València \\
\hline 33 & $\begin{array}{l}C(\text { ai) Manli Cn(aei) } \\
\text { f(ilii) Ser }(\text { gia) } \\
\text { Toloconi }[s]^{57}\end{array}$ & CIL II 1389 & 30 в.с. -14 в.с. & funerary & $\begin{array}{l}\text { Fuentes de Anda- } \\
\text { lucía, Sevilla }\end{array}$ \\
\hline 34 & $\begin{array}{l}M \text { (arcus) Horatius } \\
M \text { (arci) f(ilius) } \\
\text { Gal(eria) Bodonilur }\end{array}$ & CIL II 2114 & 30 в.C. - A.D. 30 & funerary & Arjonilla, Jaén \\
\hline 35 & $\begin{array}{l}Q \text { (uinto) Iunio } \\
Q(\text { uinti) f(ilio) } \\
\text { Gal(eria tribu) } \\
\text { Aenibeli }\end{array}$ & CIL II 3621 & 1c. A.D. & $\begin{array}{l}\text { honorific } \\
\text { pedestal }\end{array}$ & Xàtiva, València \\
\hline 36 & $\begin{array}{l}{[-S] \text { ulpicio L(uci) }} \\
\text { f(ilio) Gal(eria) } \\
\text { Ennagael[i } \\
\text { La]cetano(?) }\end{array}$ & $H E p$ 18, 452 & 1c. A.D. & ? & Torrent, València \\
\hline
\end{tabular}

Table 9: Praenomen + nomen + Latin patronymic + (tribus) + Iberian cognomen + (origo)

\begin{tabular}{|c|c|c|c|c|c|}
\hline No. & Name & Published & Date & Inscription & Provenance \\
\hline 37 & $\begin{array}{l}\text { Aurelio Tanne- } \\
\text { paeseri(Dat.) }\end{array}$ & CIL II 5840 & 1c. в.c. -1 c. A.D. & funerary & Obarra, Huesca \\
\hline 38 & $\begin{array}{l}\text { Vi(bius) } \\
\text { Turi<n>nu[s] }]^{58}\end{array}$ & $\begin{array}{l}H E p \text { 5, 913; } \\
A E \text { 1997, } 932\end{array}$ & & $\begin{array}{l}\text { votive (dedi- } \\
\text { cation to } \\
\text { Jupiter) }\end{array}$ & Asín, Zaragoza \\
\hline 39 & Fulvius Abiner & $I R C \mathrm{~V} 11$ & 1c. A.D. & $\begin{array}{l}\text { graffito on } \\
\text { pottery }\end{array}$ & Isona, Lleida \\
\hline 40 & $\begin{array}{l}\text { Aemilio Or[d]unetsi } \\
\text { Dat. }\end{array}$ & $\begin{array}{l}H E p 3,1993, \\
267 ; A E 1951, \\
283\end{array}$ & 1c. A.D. & funerary & Muez, Navarra \\
\hline 41 & Att(ius) Esdop[eles & $A E$ 1992, 1940 & 1c. A.D. & funerary & $\begin{array}{l}\text { Tocolosida, } \\
\text { Morocco }\end{array}$ \\
\hline
\end{tabular}

Table 10: Latin nomen + Iberian cognomen

(as, for instance, in table 8). Another aspect that is important to point out, as has already been done repeatedly in relation to Hispanic onomastics, is that most nomina are of Italian origin, showing the clientship ties between local

\footnotetext{
${ }^{57}$ Usually edited as Toloconi [s], although the inscription is lost and the reading is not entirely clear.

${ }^{58}$ The reading is doubtful; maybe Iturinu[s---] (see HEpOl. 16114).
} 


\begin{tabular}{|c|c|c|c|c|c|}
\hline No. & Name & Published & Date & Inscription & Provenance \\
\hline 42 & $\begin{array}{l}\text { Calpurnia Severa } \\
\text { Tannegaldunis f(ilia) }\end{array}$ & CIL II 4040 & $\begin{array}{l}30 \text { B.c. }- \\
\text { A.D. } 68\end{array}$ & funerary & Borriol, Castelló \\
\hline 43 & $\begin{array}{l}\text { Semp(ronius) Nigrinus } \\
\text { Agirsaris f(ilius) }\end{array}$ & $H E p$ 7, 586 & $\begin{array}{l}\text { ca } 27 \text { в.C.- } \\
\text { A.D. } 68\end{array}$ & funerary & $\begin{array}{l}\text { Lumbreras - San } \\
\text { Andrés, La Rioja }\end{array}$ \\
\hline 44 & $\begin{array}{l}\text { L(ucio) Aemilio Montano } \\
\text { Bacasitano Lacerilis f(ilio) }\end{array}$ & CIL II 4625 & 1c. A.D. & funerary & Empúries, Girona \\
\hline 45 & $\begin{array}{l}\text { Cornel[i]us Viator } \\
\text { Arancisis f(ilius) }\end{array}$ & $\begin{array}{l}H E p \text { 3, 363; } \\
\text { HEp 15, } 337\end{array}$ & & funerary & Vizmanos, Soria \\
\hline 46 & $\begin{array}{l}\text { Ae(milius) Severus } \\
\text { Agirseni }\end{array}$ & $\begin{array}{l}\text { HEp } 3,363 ; \\
H E P \text { 15, } 337\end{array}$ & & funerary & Vizmanos, Soria \\
\hline 47 & $\begin{array}{l}\text { Corneli Erdoild[ir } \\
\text { f(ilius) }\end{array}$ & $\begin{array}{l}\text { Ferrer- } \\
\text { Velaza- } \\
\text { Olesti } 2018\end{array}$ & Augustan & $\begin{array}{l}\text { rock } \\
\text { inscription }\end{array}$ & $\begin{array}{l}\text { Oceja, Pyrénées- } \\
\text { Orientales }\end{array}$ \\
\hline
\end{tabular}

Table 11: Latin duo or tria nomina + (origo) + Iberian patronymic

inhabitants and governors or notables who probably acted as patrons in the process of Romanization. ${ }^{59}$

Finally, as regards gender, and as we might expect, fewer women are attested than men-19 individuals out of 59 , or $32 \%$. However, in relative terms, this percentage is not negligible considering that women are generally less present than men in Latin epigraphy. Although the documentation is too scarce to draw firm conclusions from this fact, it is not impossible that this could be related to an active attitude on the part of Iberian women towards their traditional culture and language. ${ }^{60}$

\section{CONCLUSIONS}

The spread of Latin in Hispania and the progressive regression of local languages is a very complex phenomenon about which many questions remain open. What seems undeniable is that the Latinization of this territory took place through two different vectors. Latin was, on the one hand, the language used by the Italic settlers in Hispania, ${ }^{61}$ who continued to use their usual language as the main medium of communication for the provincial administration, even for those issues that directly concerned the locals. There is in fact no evidence suggesting that the Roman authorities used, even sporadically, the in-

\footnotetext{
${ }^{59}$ See, for example, Badian 1958; Dyson 1980; Mayer 1998; Amela 2001; García Fernández 2011.

${ }^{60}$ Curchin (2004: 205-206) arrives at a similar conclusion for central Spain. On women and language conservatism, see also Clackson 2012: 50-52.

${ }^{61}$ On Italic emigration to Hispania, see, for example, Diod. 5.36.3. See also Marín 1988; Le Roux 1995a.
} 


\begin{tabular}{|c|c|c|c|c|c|}
\hline No. & Name & Published & Date & Inscription & Provenance \\
\hline 48 & $\begin{array}{l}\text { Calpurniae } \\
\text { Vrchatetelli (Dat.) }\end{array}$ & CIL II 2967 & 1c. A.D. & funerary & $\begin{array}{l}\text { Mendigorría - } \\
\text { Andión, Navarra }\end{array}$ \\
\hline 49 & Iunia Tannegadinia & CIL II 3796 & $\begin{array}{l}\text { A.D. } 51- \\
\text { A.D. } 100\end{array}$ & funerary & Llíra, València \\
\hline 50 & Aelia Belesiar & $\begin{array}{l}\operatorname{HEp} 16,2007 \\
446\end{array}$ & $\begin{array}{l}\text { 1с в.C.- } \\
\text { 1с A.D. }\end{array}$ & $\begin{array}{l}\text { votive (dedi- } \\
\text { cation to the } \\
\text { indigenous } \\
\text { god Betatun) }\end{array}$ & $\begin{array}{l}\text { Fuerte del Rey, } \\
\text { Jaén }\end{array}$ \\
\hline 51 & Caecilia Geseladin & $H E p$ 5, 636 & 1c. A.D. & funerary & $\begin{array}{l}\text { Valpalmas, } \\
\text { Zaragoza? }\end{array}$ \\
\hline 52 & [---]a Galduriaunin & $C I L \mathrm{II}^{2} / 7,26$ & A.D. $1-30$ & funerary & Jódar, Jaén \\
\hline 53 & [Cae]cilia [--]reiun & $A E$ 2008, 742 & 1 c. A.D. & funerary & Llíria, València \\
\hline 54 & $\begin{array}{l}\text { Pompeia } M \text { (arci) } \\
\text { f(ilia) Bileseton }\end{array}$ & CIL II 3537 & 1c. A.D.? & funerary & Cehegín, Murcia \\
\hline 55 & $\begin{array}{l}\text { Annia L(uci) f(ilia) } \\
\text { Bilosoton }\end{array}$ & $H E p$ 8, 297 & 1c. A.D. & funerary & Espeluy, Jaén \\
\hline 56 & $\begin{array}{l}\text { Titiniae P(ubli) } \\
\text { f(iliae) } \\
\text { Bastogaunini (Dat.) }\end{array}$ & CIL II 6144 & 1с. в.с. & funerary & $\begin{array}{l}\text { Terrassa, } \\
\text { Barcelona }\end{array}$ \\
\hline 57 & $\begin{array}{l}\text { Cornelia L(uci) } \\
\text { f(ilia) Sirasteiun }\end{array}$ & $\begin{array}{l}A E \text { 1994, 1059; } \\
H E p \text { 6, 1996, } \\
908\end{array}$ & 1c. A.D. & funerary & Alcañiz, Teruel \\
\hline 58 & $\begin{array}{l}\text { Lucretia L(uci) } \\
\text { f(ilia) Sergieton }\end{array}$ & CIL $\mathrm{II}^{2} / 7,91$ & Augustan & funerary & Arjonilla, Jaén \\
\hline 59 & $\begin{array}{l}\text { Corneliae L(uci) } \\
\text { f(iliae) Sillibori } \\
\text { Vetuli }\end{array}$ & CIL II 3351 & 1c. A.D. & honorific & $\begin{array}{l}\text { Mancha Real - } \\
\text { Cerro Alcalá, } \\
\text { Jaén }\end{array}$ \\
\hline
\end{tabular}

Table 12: Latin feminine nomen + (patronymic) + Iberian cognomen + (gamonymic)

digenous languages in order to communicate with local communities. ${ }^{62}$ On the other hand, we must also take into account the active role of the local inhabitants, who progressively adopted the use of Latin. The documentation under study, which shows the mechanisms by which Iberians adopted Roman nomenclature and started to express themselves in Latin in the epigraphic register, is particularly relevant to understanding this process, especially when considered alongside the data available for other areas of Hispania and the evolution and extinction of the local writing practices.

Another point to keep in mind is that the Latinization of Hispania did not occur in a homogeneous manner throughout the territory. This was mainly due to the cultural and ethnic diversity of the Peninsula, which was inhabited by different Indo-European groups but also by non-Indo-European peoples, such

${ }^{62}$ Díaz Ariño 2008: 38-39. 
as the Iberians. The study of Iberian onomastics as a separate corpus is therefore helpful to study the ways local communities reacted to Romanization. In the first place, Iberian names in Latin epigraphy are less frequent than names belonging to other languages spoken in central Spain and throughout the Cantabrian and Atlantic basins, where writing was unknown before the arrival of the Romans. In these regions the presence of indigenous onomastics in Latin is much more widespread and long-lasting, providing several thousand occurrences. By contrast, on the Mediterranean coast, where a local written culture had developed long before the Roman conquest as a result of contacts with Phoenicians and Greeks, the presence of indigenous names in Latin inscriptions would be more sporadic, comprising just the cases compiled in this study. This could be an indication that in the Iberian area, where the Roman conquest also started sooner, the local languages disappeared at an earlier stage, whereas in central and north-western Hispania they lasted much longer. The survival of Basque until today is the strongest evidence for this phenomenon.

From a linguistic point of view, an accurate analysis of the different ways in which Iberian names are rendered into Latin also provides us with some sociolinguistic data regarding the progressive extinction of the Iberian language. The phonetic transcription does not imply a direct knowledge of the original language of these names, whereas the sporadic cases of respect for the original spelling could imply, at least, that the Palaeohispanic script was still known by the person who was writing. Moreover, the spread of Iberian names to other linguistic areas-Turdetanian, Celtiberian, Vasconic, and Aquitanianduring Roman times reveals a greater mobility of the indigenous population in this period, and a world that was becoming more and more global, and for which a lingua franca, Latin, was becoming a necessity. After a first period of multilingualism, in which some syncretism between the different local cultures occurred, as we have seen with the formation of some hybrid onomastic formulae where Iberian elements are mixed with Celtic ones, this linguistic melting pot inexorably evolved towards a more monolingual society.

Besides the linguistic analysis regarding the Latinization of Iberian names, it is also necessary to consider the Romanization of naming patterns. In this regard, the most interesting phenomenon under study is the way Iberians adapted their names to Roman naming habits as they climbed the Roman social ladder, with the grant of citizenship. Changing names went hand in hand with juridical Romanization, and, probably, with linguistic Latinization as well. However, it is possible to perceive different linguistic attitudes towards the abandonment of indigenous onomastics: sometimes, the name was Latinized even before the grant of Latin or Roman citizenship; sometimes, the Iberian name was abandoned when one became a citizen; in some cases, the Iberian name was transmitted for at least two generations after the bearers became Roman. In all cases, however, the direction of the onomastic change is straightforward: the oldest generations bear Iberian names, whereas the youngest have switched to Latin 
onomastics (e.g., the son of Marcus Porcius Escerior is Marcus Porcius Nigrinus; the son of Calpurina Vrchatetel is Lucius Aemilius Seranus; the granddaughter of Iunia Tannegadinia is Atilia Potita, and so on). As a matter of fact, there is not a single case where this trend is broken, as could have happened for instance as a result of a conscious linguistic choice to express cultural resistance or of the impossibility of transmitting citizen status from parent to child.

The dating of these inscriptions is also especially relevant, as it allows this changeover period to be chronologically framed. Although there are some instances dating back to the republican period, most of the inscriptions belong to the first century A.D., with a few cases that could even reach the beginning of the second century A.D. This means that the peak of this phenomenon occurred between the time when Palaeohispanic languages ceased to be written, in the Augustan period, ${ }^{63}$ and the complete Latinization (at least from an epigraphic perspective) of local communities in the second century A.D. During this period of two centuries, the Iberian language is only traceable through onomastics, just before its final extinction from the written record. In this sense, this period when Iberian-name bearers expressed their identity in Latin by means of the Roman epigraphic habit can be seen as the moment heralding the disappearance of the Iberian language, ${ }^{64}$ after more than two centuries of bilingualism during which Latin and Iberian were both used in the written register and shared, in some important cities such as Emporiae, Tarraco, or Saguntum, the same epigraphic landscape.

If we analyse the chronological scope of this documentation in more detail, we can observe some significant behavioural differences between Iberian territories: the indigenous elites differ in their way of displaying their linguistic identity in Hispania Citerior and Ulterior. Under the republic, Iberian names in Latin inscriptions are scarce and mainly come from Ulterior, a province which has been traditionally considered as more strongly Romanized. The fact that the earliest Iberian onomastics in Latin sources come from Hispania Ulterior, could confirm Strabo's view (3.2.15), or at least show that the language chosen by local people shortly after the Roman conquest was mainly Latin. In the same period, on the other hand, Iberian onomastics in Citerior almost exclusively appear in Iberian texts. This phenomenon should be connected with the increasing number of Iberian inscriptions during the republic, which doubles the documentation of the pre-Roman period. ${ }^{65}$ In fact, the first centuries of Roman rule show a development of local epigraphic practices in the north-east, not only because the corpus increased in size numerically, but also because writing was adopted in new territories and for new forms of expression, including public and monumental texts in Iberian and other kinds of official epigraphy, such as coinage. This

\footnotetext{
${ }^{63}$ Simón 2013b: 167-186.

${ }^{64}$ For the relationship between onomastic change and linguistic assimilation, see Adams 2003: 290.

${ }^{65}$ Moncunill and Velaza 2017: 33.
} 
situation suggests that during the first centuries of Romanization, the local elite in the north-east not only did not abandon their own identity, but actually developed new epigraphic uses for their mother tongue. It is probable that adhesion to Rome- which is possible to perceive, in parallel, in the evolution of material culture, architecture, and the urbanization of public space-was not seen by Iberians as incompatible with the manifestation of a strong local idiosyncrasy implying the public use of the local language. In the Augustan age, however, this status quo seems to have changed dramatically: as the Iberian script fell into disuse, Iberian onomastics started to appear in Latin inscriptions also in Citerior, and mostly in the form of cognomina of individuals with a privileged status in provincial society. However, this phenomenon was never as intense here as in other provinces, and it did not last for more than a century after the loss of the local written culture.

In conclusion, the Latinization of Iberian names is, therefore, direct evidence of a strong and profound transformation process that intensified during the time of Augustus and which seems to have been almost complete at the beginning of the second century A.D.: the adaptation of Iberian names to Roman onomastic conventions shows a continuous path towards the cultural transformation of Iberians, just a short time, as Strabo puts it, before they would become Romans. ${ }^{66}$

Universitat de Barcelona

Facultat de Filologia i Comunicació

Gran Via de les Corts Catalanes, 585

08007 BARCELONA

SPAIN

nmoncunill@ub.edu

\section{ABBREVIATIONS}

AE: L'Année Epigraphique. Paris.

BDH: Hesperia. Banco de Datos de Lenguas Paleohispánicas (http://hesperia.ucm.es/).

CIL: Corpus Inscriptionum Latinarum. Berlin.

CILA: Corpus de Inscripciones Latinas de Andalucia. Seville.

EE: Ephemeris Epigraphica. Berlin.

ELRH: Epigrafia latina republicana de Hispania. Barcelona.

HEp: Hispania Epigraphica. Madrid.

HEpOl: Hispania Epigraphica Online. Alcalá de Henares.

IRC: Inscriptions Romaines de Catalogne. Murcia.

MLH: Monumenta Linguarum Hispanicarum. Wiesbaden.

TLE: Thesaurus Linguae Etruscae. Rome.

\footnotetext{
${ }^{66}$ This work has been supported by the following institutions and research projects: LITTERA Group, University of Barcelona; "Estudio paleográfico, lingüístico y funcional del corpus epigráfico ibérico" (Spanish Ministry of Science and Innovation, grant agreement no. PID2019-106606GBC33); LatinNow (ERC, grant agreement no. 715626).
} 
Abascal, J. M. 1994. Los nombres personales en las inscripciones latinas de Hispania. Murcia. and S. F. Ramallo. 1997. La ciudad de Carthago Nova: la documentación epigráfica. Murcia.

Adams, J. N. 2003. Bilingualism and the Latin Language. Cambridge.

— 2003a. “'Romanitas' and the Latin Language,” CQ N.s. 53: 184-205.

Albertos, M. L. 1966. La onomástica personal primitiva de Hispania: Tarraconense y Bética. Salamanca.

Alföldy, G. 1966. "Notes sur la relation entre le droit de cité et la nomenclature dans l'empire romain," Latomus 25: 37-57.

Amela, L. 2001. "E1 nomen Pompeius en Hispania: algunos aspectos críticos," Emerita 69: 241-262.

Badian, E. 1958. Foreign Clientelae (264-70 B.C.). Oxford.

Barrandon, N. 2011. De la pacification à l'integration des Hispaniques (133-27 a.C.). Bordeaux.

Beltrán, F. 2011. "Lengua e identidad en la Hispania romana," Palaeohispanica 11: 19-59.

- 2012. "Roma y la epigrafía ibérica sobre piedra del nordeste peninsular," Palaeobispanica 12: 9-30.

- 2015. "Latin Epigraphy: The Main Types of Inscriptions," in C. Bruun and J. Edmondson (eds.), The Oxford Handbook of Roman Epigraphy. Oxford. 89-110.

Bernard, G. and M. Christol. 2009. "Les relations militaires entre l'Hispanie et la Maurétanie Tingitane à la fin du 1er siècle," Mélanges de la Casa de Velázquez 39: 189-208.

Chastagnol, A. 1995. La Gaule romaine et le droit latin: Recherches sur l'histoire administrative et sur la romanisation des habitants. Lyon.

Clackson, J. 2012. "Language Maintenance and Language Shift in the Mediterranean World during the Roman Empire," in A. Mullen and P. James (eds), Multilingualism in the Graeco-Roman Worlds. Cambridge. 36-57.

Cooley, A. E., 2012. The Cambridge Manual of Latin Epigraphy. Cambridge.

Correa, J. A., 2009. "Identidad, cultura y territorio en la Andalucía prerromana a través de la lengua y la epigrafía," in F. Wulff and M. Álvarez (ed.), Identidades, culturas y territorios en la Andalucía prerromana. Málaga. 273-296.

Corzo, S., M. Pastor, A. U. Stylow, and J. Utermann. 2007. "Betatun: La primera divinidad ibérica identificada," Palaeohispanica 7: 251-262.

Cranford, D. 2012. "A Roman in Name Only: An Onomastic Study of Cultural Assimilation and Integration in Roman Spain," Eras 13.2: 1-44.

Criniti, N. 1970. L'epigrafe di Ascolum di Cn. Pompeo Strabone. Milan.

Curchin, L. A. 1990. The Local Magistrates of Roman Spain. Toronto.

- 2004. The Romanization of Central Spain: Complexity, Diversity and Change in a Provincial Hinterland. London and New York.

de Hoz, J. 2010.Historia Lingüistica de la Peninsula Ibérica en la Antigüedad 1: Preliminares y mundo meridional prerromano. Madrid.

— 2011. Historia Lingüística de la Peninsula Ibérica en la Antigüedad 2: El mundo ibérico prerromano y la indoeuropeización. Madrid.

— 2016. "Los turdetanos. Quiénes eran y que hablaban," Cadernos do museu de Lucerna 2: 200-228. 
Díaz Ariño, B. 2008. Epigrafia latina republicana de Hispania. Barcelona.

— forthcoming. "Culture écrite, latinisation et épigraphie dans l'Hispanie Citérieure républicaine," in M. Coltelloni-Trannoy and N. Moncunill, La culture de l'ecrit en Méditerrannée occidentale à travers les pratiques épigraphiques. Paris.

Dondin-Payre, M. 2011. "Introduction," in M. Dondin-Payre (ed.), Les noms de personnes dans l'empire romain: Transformations, adaptation, évolution. Bordeaux. 13-36.

— 2012. "Les processus d'adaptation des onomastiques indigènes à l'onomastique romaine," in T. Meissner (ed.), Personal Names in the Western Roman World. Berlin. 25-40.

— and M.-T. Raepsaet-Charlier. 2001. "L'onomastique dans l'Empire romain: Questions, méthodes, enjeux," in M. Dondin-Payre and M.-T. Raepsaet-Charlier (eds.), Noms, identités culturelles et romanisation sous le Haut-Empire. Brussels. i-xiv.

Dyson, S. L. 1980. "The Distribution of Roman Republican Family Names in the Iberian Peninsula," Ancient Society 11-12: 257-300.

Edmonson, J. 2014. "Reflexiones sobre el proceso e impacto de la conquista romana en la Península Ibérica," in G. Bravo and R. González (eds.), Conquistadores y conquistados: relaciones de dominio en el mundo romano. Madrid. 19-44.

Estarán, M. J. 2009. "La fórmula onomástica como fuente para el estudio del contacto lingüístico en la Antigüedad,” Salduie 9: 103-112.

— 2016. Epigrafia bilingüe del Occidente romano: El latín y las lenguas locales en las inscripciones bilingües y mixtas. Zaragoza.

Faria, A. M. de. 2000-18. "Crónica de onomástica paleo-hispânica," published between 2000 and 2018 in Revista Portuguesa de Arqueologia.

— 2009. "Crónica de onomástica paleo-hispânica (16)," Revista Portuguesa de Arqueologia 12: 157-175.

— 2015. "Crónica de onomástica paleo-hispânica (22)," Revista Portuguesa de Arqueologia 18: 125-146.

— 2016. “Crónica de onomástica paleo-hispânica (23),” Revista Portuguesa de Arqueologia 19: 155-174.

Ferrer, J. 2017. “Algunas reflexiones sobre la genealogia de las escrituras paleohispánicas,” Palaeohispanica 17: 55-94.

— 2018. "El signo S65 de la escritura paleohispánica meridional: a propósito de la inscripción de la necrópolis de Piquía (Arjona, Jaén),” ELEA 17: 139-180.

— - J. Velaza, and O. Olesti. 2018. "Nuevas inscripciones rupestres latinas de Oceja y los IIIIviri ibéricos de Iulia Lybica," Dialogues d'Histoire Ancienne 44/1: 169-195.

García Fernández, E. 2011. "Movilidad, onomástica e integración en Hispania en época republicana. Algunas observaciones metodológicas”, in J. M. Iglesias and A. Ruiz (eds.), Viajes y cambios de residencia en el mundo romano. Santander. 51-52.

Gorrochategui, J. 1993. "La onomástica aquitana y su relación con la ibérica”, in F. Villar and J. Untermann (eds), Lengua y cultura en la Hispania prerromana: Actas del V coloquio sobre lenguas y culturas prerromanas de la Península Ibérica. Salamanca. 609-634.

— 2011. "Contactos lingüísticos y epigráficos en la zona vasco-aquitana," in C. Ruiz and E. Luján (eds.), Contacts linguistiques dans l'Occidentméditerranéen Antique. Madrid. 65-87.

Le Roux, P. 1995. Romains d'Espagne: Cités et politique dans les provinces $I I^{e}$ siècle av. J.-C.-III siècle ap. J.-C. Paris. 
1995a. "L'émigration italique en Citérieure et Lusitanie jusqu'à la mort de Néron", in F. Beltrán (ed.), Roma y el nacimiento de la cultura epigráfica en occidente. Zaragoza. 85-95.

Luján, E. R. 2013. “La situación lingüística de la meseta sur en la antigüedad,” Palaeobispanica 13: 103-136.

— 2014. "Sobre las fórmulas onomásticas en la Hispania antigua," in J. J. Ortega and M. V. Navas (eds.), Del nombre oficial al nombre familiar (apodos, sobrenombres e bipocorísticos). Madrid. 73-96.

Marín, M. A. 1988. Emigración, colonización y municipalización en la Hispania republicana. Granada.

Mayer, M. 1998. “Aproximación al proceso de urbanización de Hispania citerior a través de la onomástica," in A. Rodríguez Colmenero (ed.), Los orígenes de la ciudad en el noroeste hispánico. Lugo. 295-307.

— 2002. "El proceso de adopción de la fórmula onomástica romana," Palaeohispanica 2: $189-200$.

— and J. Velaza. 1993. "Epigrafía ibérica sobre soportes típicamente romanos," in F. Villar and J. Untermann (eds.), Lengua y cultura en la Hispania prerromana: actas del $V$ coloquio sobre lenguas y culturas prerromanas de la Península Ibérica. Salamanca. 667-682.

Moncunill, N. 2017. "Indigenous Naming Practices in the Western Mediterranean: The Case of Iberian," Studia Antiqua et Archaeologica 23: 7-20.

— and J. Velaza. 2017. Iberian: Language, Writing, Epigraphy. Zaragoza.

Mullen, A. 2007. 'Linguistic Evidence for 'Romanization': Continuity and Change in Romano-British Onomastics. A Study of the Epigraphic Record with Particular Reference to Bath,” Britannia 38: 36-38.

— 2012. "Introduction: Multiple Languages, Multiple Identities," in A. Mullen and P. James (eds.), Multilingualism in the Graeco-Roman Worlds. Cambridge. 1-35.

- 2013. Southern Gaul and the Mediterranean: Multilingualism and Multiple Identities in the Iron Age and Roman Periods. Cambridge.

Palomar, M. 1957. La onomástica personal prelatina de la antigua Lusitania. Salamanca.

Raepsaet-Charlier, M.-T. 2009. "Citoyenneté et nomenclature: L'exemple de la Gaule du Nord," in F. Hurlet (ed.), Rome et l'Occident (IIe siècle av. J-C.-IIe siècle apr. J-C.): Gouverner l'Empire. Rennes. 359-382.

Richardson, J. S. 1986. Hispaniae: Spain and the Development of Roman Imperialism, 218-82 B.C. Cambridge.

Rodríguez Ramos, J. 2001. "El término (t)eban(en) en la lengua íbera: 'coeravit' vs. 'filius'," Arse 35: 59-85.

— 2010. "La inscripción CILA III,1 n.o 216, la romanización onomástica y la pervivencia de elementos indígenas en la Cástulo romana," Veleia 27: 123-133.

- 2014. "Nuevo índice crítico de formantes de compuestos de tipo onomástico íberos," Arqueoweb: Revista sobre Arqueología en Internet 15: 1-158.

Schuchardt, H. 1909. "Iberische Personennamen," Revista Internacional de Estudios Vascos 3: $237-247$.

Simón, I. 2013a. Los soportes de la epigrafía paleohispánica: Inscripciones sobre piedra, bronce y cerámica. Zaragoza. 
— 2013b. "El final de las escrituras paleohispánicas," Acta Palaeohispanica XI = Palaeobispanica 13: 167-186.

- 2014. "Tanniber: un productor de metal de posible origen ibérico," Pallas 97: 181-192.

2015. "La onomástica de la estela de Illescas (HEp 4, no $889=A E$ 1990, no 582)," Emerita 83: 333-346.

- 2018a "C. Licinius Adin: uno de los últimos iberos," Dialogues d'Histoire Ancienne 44: 59-73.

— and C. Jordán. 2014. "Ildi: un grafito de La Alcudia de Elche (Alicante)," Archivo de Prehistoria Levantina 30: 263-273.

Untermann, J. 1965. Elementos de un atlas antroponímico de la Hispania antigua. Madrid.

- 1990. Monumenta Linguarum Hispanicarum 3.1. Wiesbaden (= MLH).

- 1984. "Inscripciones sepulcrales ibéricas," Cuaderno de prehistoria y arqueología castellonenses 10: 111-119.

Vallejo, J. 1943. "La escritura ibérica: Estado actual de su conocimiento," Emerita 11: 461-475.

Vallejo, J. M. 2016. Banco de Datos Hesperia de Lenguas Paleohispánicas (BDHESP). III. Onomástica paleohispánica. I. Antroponimia y teonimia. 1. Testimonios epigráficos latinos, celtibéricos y lusitanos, y referencias literarias. Vitoria.

Velaza, J. 1994. "Iberisch eban, teban," ZPE 104: 142-150.

- 2004. “Eban, teban, diez años después," Estudios de lenguas y epigrafía antiguas 5: 199-210.

- 2009. "Epigrafia y literacy paleohispánica en territorio vascón: notas para un balance provisional," in F. Beltrán et al. (eds.), Acta Palaeohispanica X: Actas del X Colóquio sobre linguas e culturas paleo-hispânicas. Zaragoza. 611-622.

2015. “Salaeco: un teónimo ibérico,” ZPE 194: 290-291.

Vidal, J. C. 2016. "Interpretació ibèrica de dos teònims preromans del nord-est peninsular," Revista d'Arqueologia de Ponent 26: 195-204. 


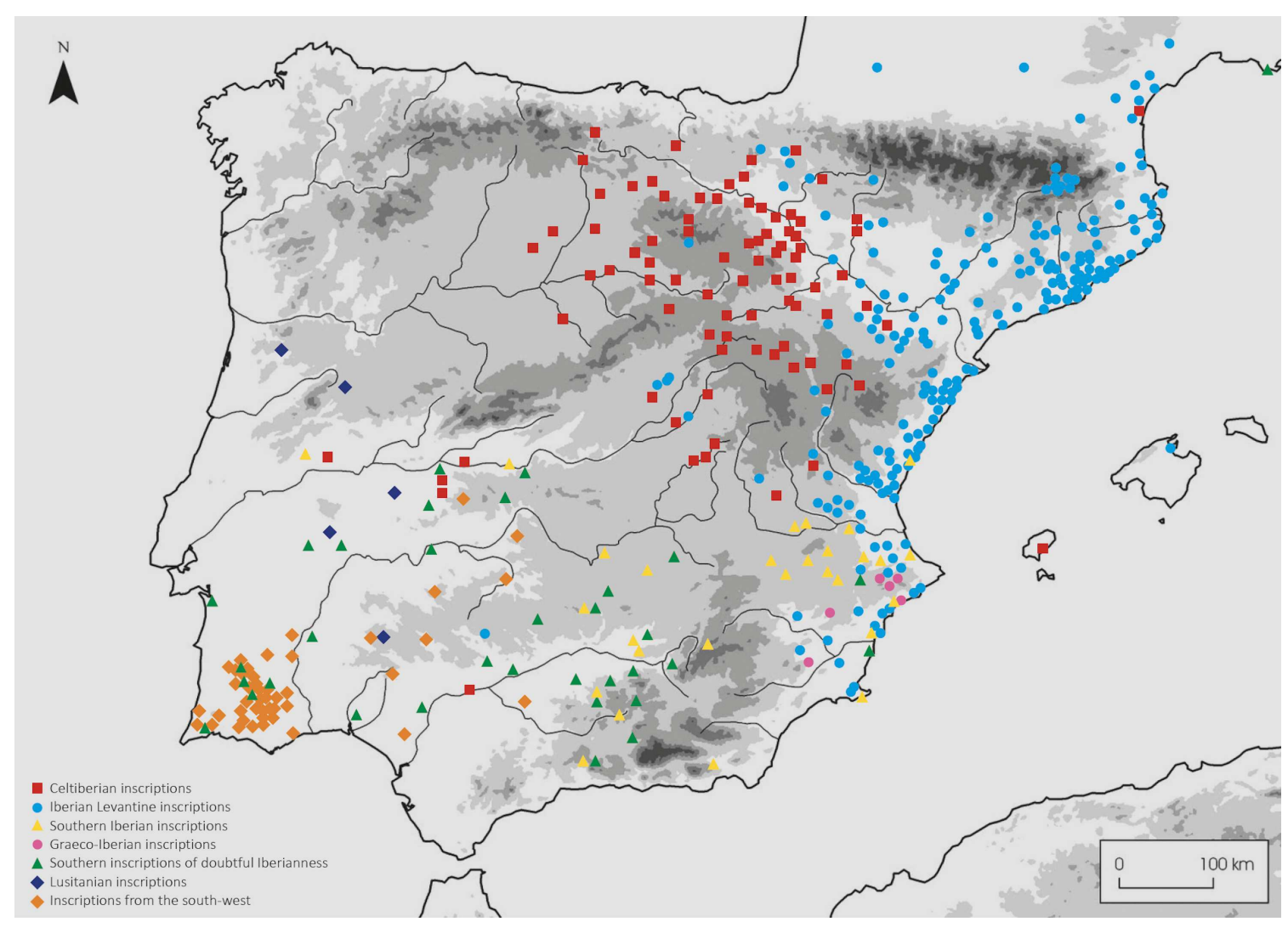

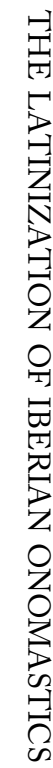

Fig. 1. Map of Palaeohispanic inscriptions. 


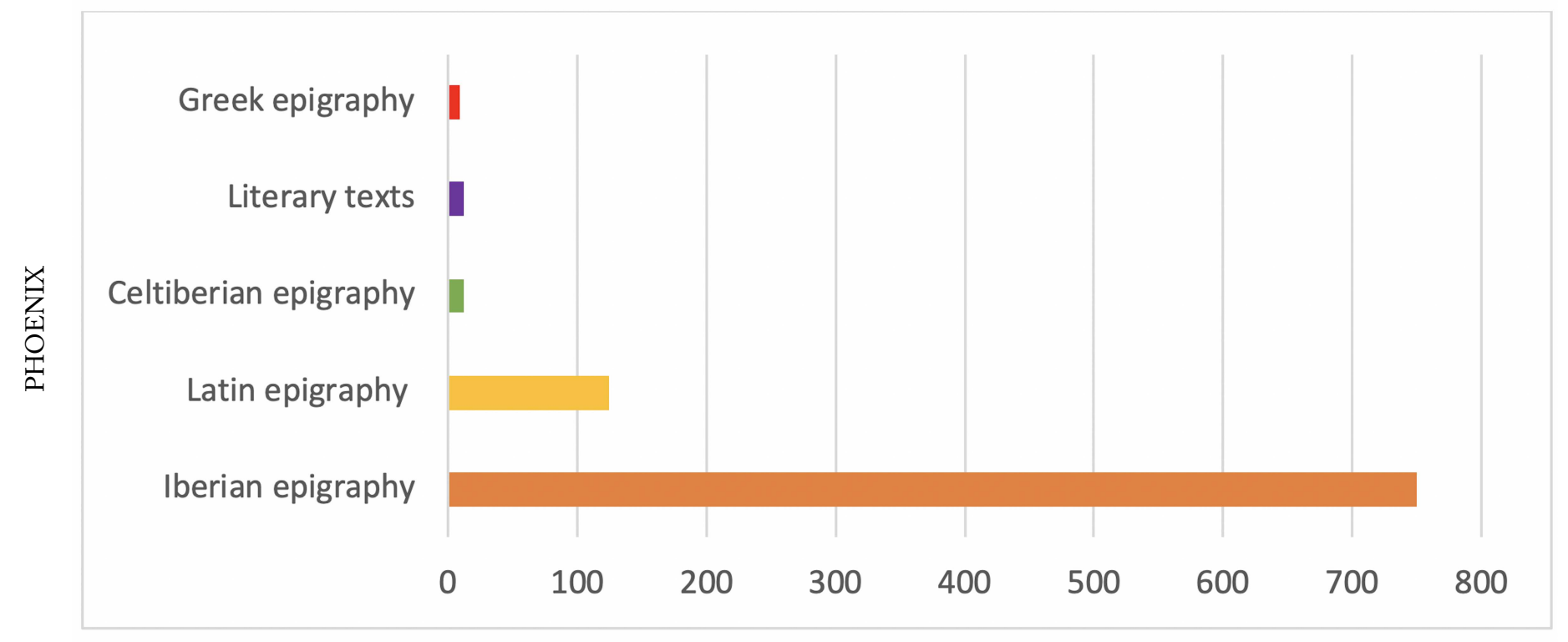

Fig. 2. Table showing the number of Iberian personal names attested by type of source, according to the data collected by the author for Hesperia Databank Onomastics (http://hesperia.ucm.es/onomastica.php). 


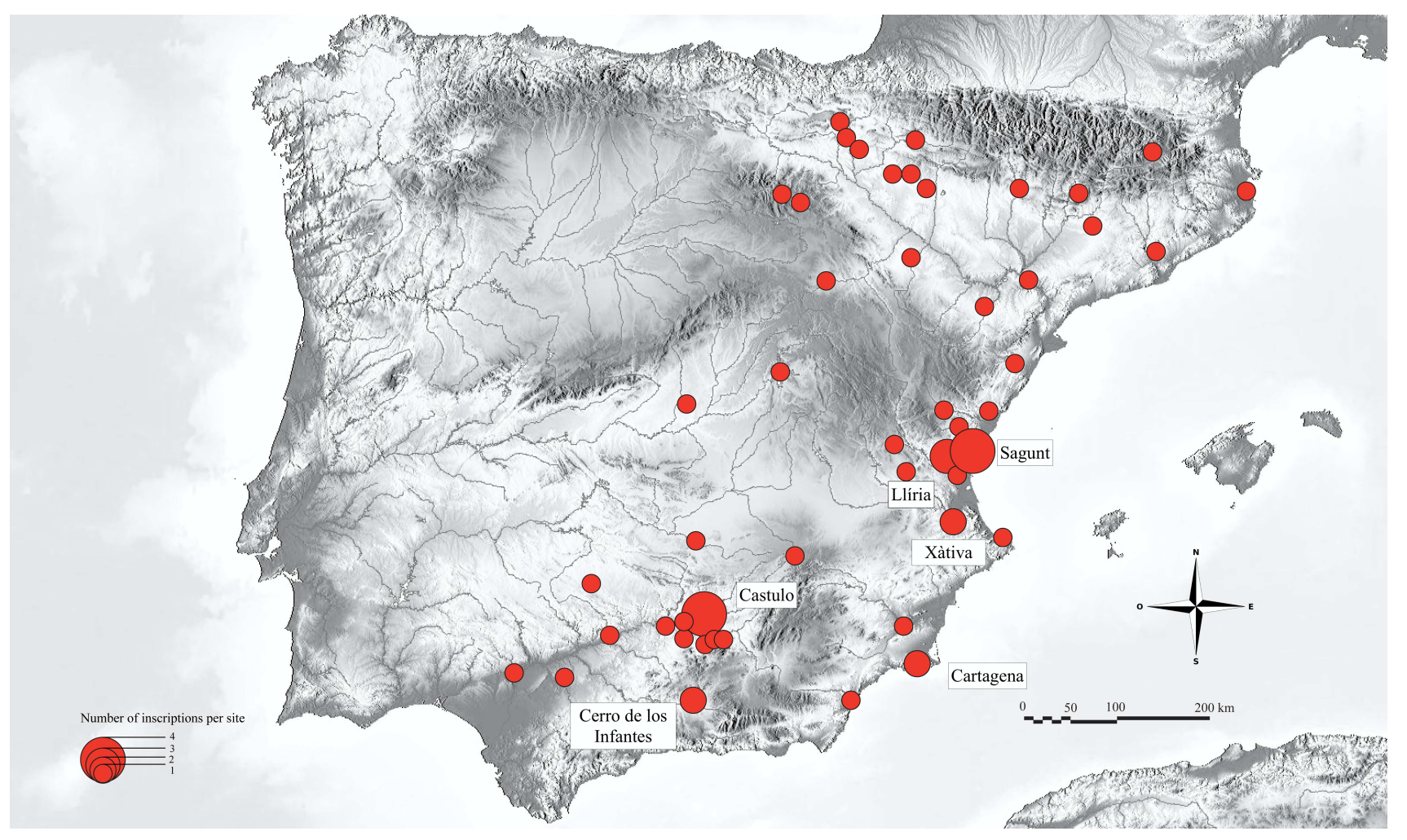

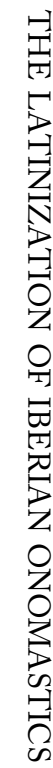

Fig. 3. Distribution of Iberian names in Latin epigraphy, with the name of the cities that have produced more documents. 


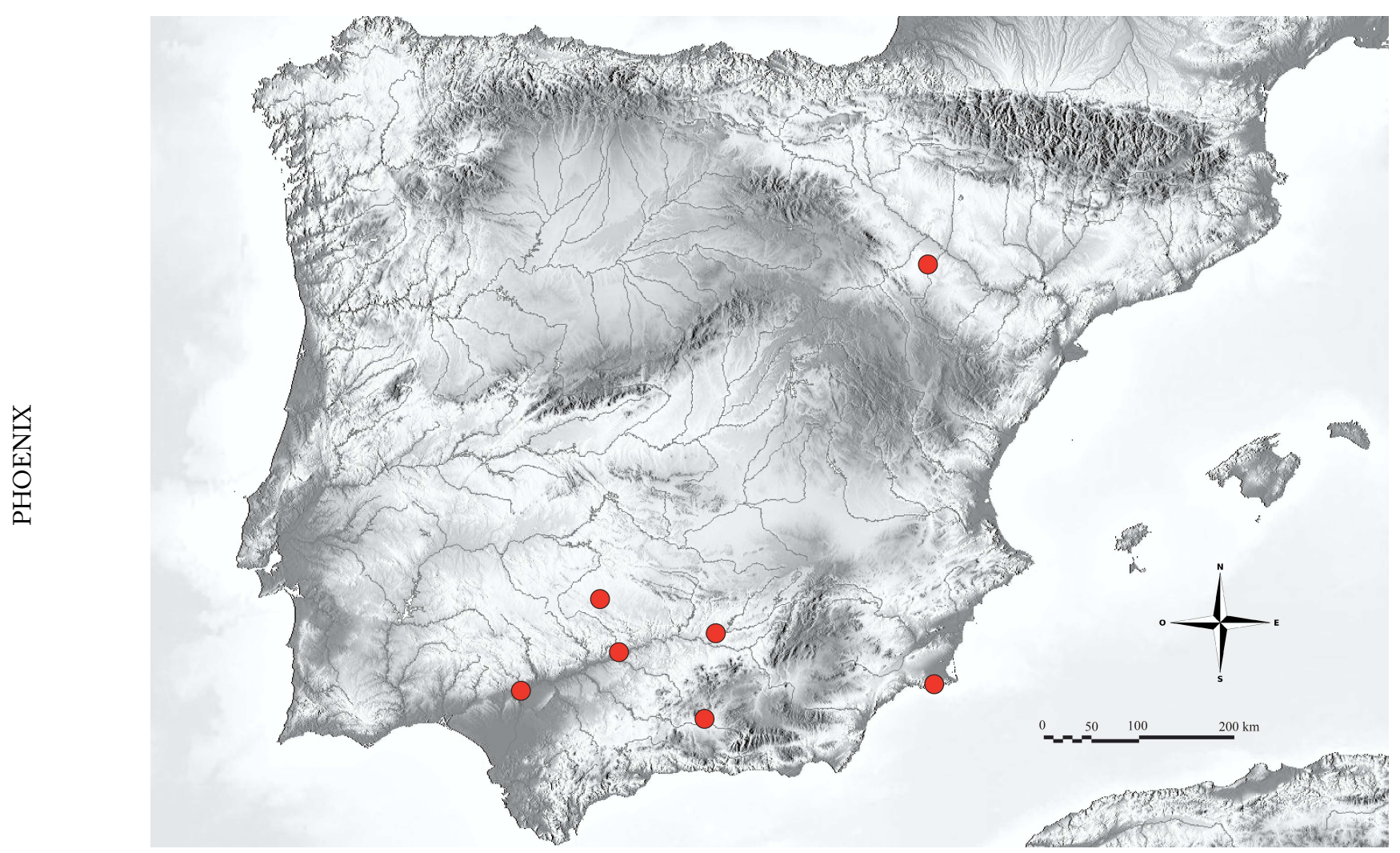

Fig. 4. Distribution of Latin republican inscriptions bearing Iberian names. 


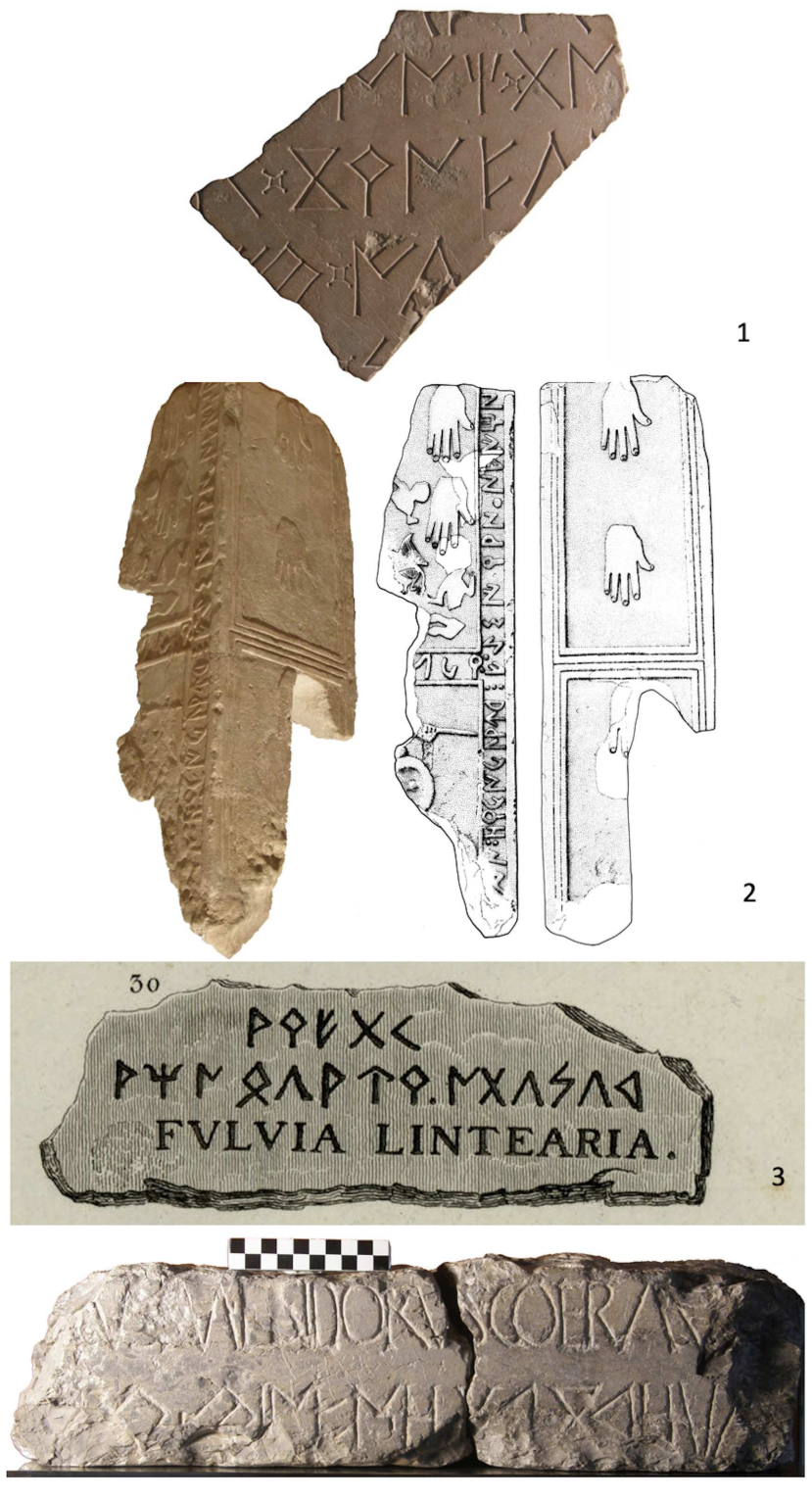

Fig. 5. Iberian republican inscriptions from Hispania Citerior bearing Iberian names: 1. inscription from Empúries bearing the nomen Cornelius (MLH C.1.1); 2. funerary inscription from Binéfar ( $M L H$ D.12.1); 3. bilingual inscription from Tarragona (ELRH C66); 4. bilingual inscription from Saguntum (ELRH C56). 